University of Montana

ScholarWorks at University of Montana

2005

\title{
Historical Context and Hazardous Waste Facility Siting: Understanding Temporal Patterns in Michigan
}

\author{
Robin Saha \\ University of Montana - Missoula, robin.saha@mso.umt.edu \\ Paul Mohai
}

Follow this and additional works at: https://scholarworks.umt.edu/environstudies_pubs

Part of the Environmental Sciences Commons

Let us know how access to this document benefits you.

\section{Recommended Citation}

Saha, Robin and Mohai, Paul, "Historical Context and Hazardous Waste Facility Siting: Understanding Temporal Patterns in Michigan" (2005). Environmental Studies Faculty Publications. 1. https://scholarworks.umt.edu/environstudies_pubs/1

This Article is brought to you for free and open access by the Environmental Studies at ScholarWorks at University of Montana. It has been accepted for inclusion in Environmental Studies Faculty Publications by an authorized administrator of ScholarWorks at University of Montana. For more information, please contact scholarworks@mso.umt.edu. 


\title{
Historical Context and Hazardous Waste Facility Siting: Understanding Temporal Patterns in Michigan
}

\author{
ROBIN SAHA, University of Montana \\ PAUL MOHAI, University of Michigan
}

This article tests the proposition that, beginning in the 1970s, historic growth of public environmental concern and opposition to waste facilities, as well as changes in the policy environment increasingly encouraged hazardous waste facilities siting to follow the path of least (political) resistance and resulted in environmental inequities. Our longitudinal analysis of sitings in the State of Michigan from 1950 to 1990 reveals a distinct temporal pattern supporting our hypotheses. Whereas significant racial, socioeconomic, and housing disparities at the time of siting were not in evidence for facilities sited prior to 1970, patterns of disparate siting were found for facilities sited after 1970. Thus, we call for environmental justice studies employing longitudinal methods to understand the processes and factors contributing to environmental inequalities with greater consideration to changes in historical context.

Environmental justice research largely has been devoted to examining social inequalities in the geographic distribution of environmental hazards such as waste facilities and other pollution sources (Brown 1995; Bullard 1983, 1990; Mohai and Bryant 1992; Ringquist 2005). Environmental justice scholars only recently have begun to examine inequitable distributions over time. Longitudinal studies focus on the temporal sequence of events that result in present day environmental inequalities by assessing social and demographic characteristics of host neighborhoods at the time noxious facilities are sited and by analyzing subsequent changes (Been 1994; Been and Gupta 1997; Krieg 1995; Oakes, Anderton, and Anderson 1996; Pastor, Sadd, and Hipp 2001; Stretesky and Hogan 1998; Szasz and Meuser 2000). This literature asks generally whether minority and low-income neighborhoods "attract" noxious land uses and whether localized negative impacts (e.g., on property values, neighborhood pride, health, and safety) lead to disproportionate demographic changes (Baibergenova et al. 2003; Freudenberg 1997; Nelson, Genereux, and Genereux 1992; Vrijheid et al. 2002). By going beyond merely asking whether environmental inequalities exist, these studies take an important step toward understanding environmental inequity formation processes and associated factors (Pellow 2000). This article tests the proposition that, beginning in the 1970s, historic growth of public environmental concern and opposition to waste facilities, as well as changes in the policy environment increasingly encouraged hazardous waste facilities siting to follow the path of least (political) resistance and resulted in disparate siting in low-income and minority neighborhoods.

This research was supported by the Sociology and Geography and Regional Science Programs of the National Science Foundation (Grant \#0099123), a Michigan State Policy Research Grant, the University of Michigan School of Natural Resources and Environment, and the Office of the Vice President for Research. The authors extend thanks to David Pellow, anonymous reviewers, and the editors of Social Problems for their helpful comments. An earlier version of this article was presented at the August 2003 Annual Meeting of the American Sociological Association, Atlanta, Georgia. Direct correspondence to: Robin Saha, University of Montana, Environmental Studies, JRH 018, Missoula, MT 59812-4320; or Paul Mohai, University of Michigan, School of Natural Resources and Environment, Ann Arbor, MI 48109-1115. E-mails: robin.saha@umontana.edu; pmohai@umich.edu.

Social Problems, Vol. 52, Issue 4, pp. 618-648, ISSN 0037-7791, electronic ISSN 1533-8533.

(C) 2005 by Society for the Study of Social Problems, Inc. All rights reserved. Please direct all requests for permission to photocopy or reproduce article content through the University of California Press's Rights and Permissions website, at http://www. ucpress.edu/journals/rights.htm. 


\section{Explanations of Hazardous Facility Location}

Environmental justice theory currently is under active development, as researchers consider the myriad factors that may account for disparities in the distribution of environmentally hazardous sites by race and socioeconomic status. Rational choice, sociopolitical, and racial discrimination models have been offered to explain discriminatory siting decisions and post-siting demographic changes that may occur in the surrounding neighborhoods (Saha and Mohai 1997). These models have often been treated as competing explanations, but in fact they may be complementary.

Rational choice models emphasize market rationality in industry site-selection decisions and in household residential-location decisions. Low-income and minority neighborhoods provide the most efficient locations for industry because land prices and compensation costs are relatively low, and industrial zones often coincide with where low-income and minority residents live (Portney 1991a). Neighborhood transition subsequent to siting occurs in response to the siting of noxious facilities and other locally unwanted land uses as relatively highincome residents vote with their feet. Their departure and the subsequent downward pressure on housing costs provide ample affordable housing for disproportionately low-income minorities, thereby creating new disparities or worsening ones that exist at the time of siting (Been and Gupta 1997).

Sociopolitical models focus on social group differences in the ability to resist siting proposals and force the clean-up of contamination (Schlosberg 1999). For example, Robert D. Bullard $(1983,1990)$ argues that siting follows the "path of least political resistance" because low-income and minority communities lack the power to influence siting decisions. Community resistance may also be lowered by the promise of jobs and tax revenues (Bohon and Humphrey 2000; Bullard and Wright 1987). At the same time, disadvantaged groups are underrepresented in industry and government where siting decisions are made and approved (Mohai and Bryant 1992). Thus, because of their political and economic vulnerability, lowincome and minority neighborhoods are less likely to defeat siting proposals and are more likely to receive proposals deflected from more politically powerful (i.e., affluent, white) areas.

Racial discrimination models posit that minority communities are targeted intentionally for reasons of prejudice, beliefs in racial superiority, or a desire to protect racial group position (Pulido 2000). Racial discrimination also can take an institutionalized form not necessarily directly related to racist ideologies; for example, informal or formal land use and siting decision rules of industry and government that might appear race neutral, nevertheless, might lead to racially disparate outcomes (Feagin and Feagin 1986). Moreover, discrimination in various institutional domains, such as housing, education employment, and health care, and interactions thereof, can disadvantage minorities and limit their social and physical mobility (Mohai and Bryant 1992; Pellow 2002; Stretesky and Hogan 1998).

A common assumption underlying all these models is that the undesirability of hazardous waste and polluting industrial facilities and social, economic, and political factors affecting their placement have been constant over time. Testing of these models has produced mixed results. Some studies have reported evidence of racial and socioeconomic siting disparities (Been 1994; Hurley 1997; Pastor et al. 2001). Some have found evidence of post-siting demographic change (Mitchell, Thomas, and Cutter 1999; Stretesky and Hogan 1998). Still others have found evidence supporting neither (Been and Gupta 1997; Oakes et al. 1996).

We believe that part of the ambiguity of these studies relates to inconsistencies produced by relying on census tracts of widely varying sizes and with boundaries that shift from decade to decade (Mohai and Saha 2003). Recently, the problem of shifting tract boundaries, and hence of the shifting size of neighborhoods around hazardous sites, has been overcome by examining consistent geographic areas around such sites using Geographic Information Systems (GIS) technology (e.g., see Pastor et al. 2001). Another possible explanation for the ambiguous results may be the different temporal scopes of these studies. Despite implicit 
assumptions that the social, economic, and political factors affecting siting decisions are constant over time, factors in one historical period may have been more or less influential than in another. In this article we argue that the historical context of hazardous waste facility siting, in fact, has been changing significantly over the last 50 years, as public concerns about toxic contamination have grown and as industry and government responses have evolved.

By historical context, we mean the sociopolitical conditions at any given time that may affect siting outcomes. These include public attitudes and behaviors regarding hazardous waste, institutional arrangements of siting decision-making authority, and political opportunity structure for public participation in siting decisions. We argue that the latter two factors largely have been shaped by the policy environment (i.e., the laws governing the siting process, which in turn have been shaped by the emergence of mass environmental concern).

Our purpose then is to explain how and why the historical context of hazardous waste facility siting has been changing and to explore the consequences of these changes for racial and socioeconomic disparities in siting. We do so through an empirical analysis of temporal patterns of commercial hazardous waste siting in Michigan from 1950 to 1990. As Manuel Pastor, Jr., Jim Sadd, and John Hipp (2001) have done, we attempt to remove spatial ambiguity across census decades by mapping precise facility locations and controlling the geographic areas examined around their locations by using GIS methods. In considering the various factors influencing siting decisions that have changed over time, we analyze the historical development of environmental concern about waste facilities and the anti-toxics and environmental justice movements (Gottlieb 1993; Szasz 1994). We also examine changes in the political opportunity structure (in the narrow sense of "proximate" or "policy specific opportunities") for potential host communities (Tarrow 1996:42). Thus, we consider how changes in federal-state-local institutional arrangements, brought about by the Resource Conservation and Recovery Act (RCRA), channeled and constrained social group participation in governmental siting decisions. We suggest that consideration of historical context can improve the explanatory value of environmental justice research models.

\section{Historical Context and Siting of Hazardous Waste Facilities}

We provide below an historical account of the development of public environmental concern about solid and hazardous wastes and the associated Not-in-My-Backyard (NIMBY) phenomenon. We delineate three distinct periods relevant to understanding public attitudes and anxieties about hazardous waste, social group political participation in siting decisions, and their effects on facility siting outcomes. These periods include: (1) the pre-NIMBY/preRCRA era (pre-1970); (2) the early NIMBY era (1970-1980); and 3) the post-Love Canal era (post-1980). We hypothesize that disparate siting patterns did not exist for facilities sited in the pre-NIMBY/pre-RCRA era, but that such patterns emerged in the early NIMBY era, and increased in severity in the post-Love-Canal era.

\section{Pre-NIMBY/Pre-RCRA Era (Pre-1970)}

The unprecedented growth in public awareness and concern during the 1960s and early 1970 s about a wide range of environmental issues likely had a primary influence on the siting process. In addition to growing public concern about air and water pollution, population control, and natural resource protection, concern about waste disposal also developed during the 1960s, and would later expand in the 1970s (Dunlap 1992; Kanagy, Humphrey, and Firebaugh 1994). To address concerns about adverse health and environmental impacts of evergrowing amounts of solid waste, Congress passed the Solid Waste Disposal Act of 1965 and the Resource Recovery Act of 1970, which together created a limited federal role in solid waste management. These laws encouraged states and municipalities to shift from open 
dumping to sanitary landfills by providing grants, training programs, and technical standards. Prior to 1965, few states participated in waste management activities (Blumberg and Gottlieb 1989).

Although solid waste issues were squarely on the public agenda, hazardous wastes were not, and would not be until the Love Canal story broke in 1979 (see below). Prior to the enactment of RCRA of 1976 and the Hazardous and Solid Waste Amendments of 1984 no national policies regulated the siting of hazardous waste facilities. A similar situation existed at the state level. For example, in Michigan, no specific state policies provided oversight of hazardous waste facility siting until the passage of the state Hazardous Waste Management Act (Act 64) of 1979. The so-called Superfund Act (Comprehensive Environmental Remediation, Compensation, and Liability Act of 1979, or CERCLA) and its list of abandoned, contaminated sites are testimony to prior decades of unregulated handling of hazardous waste.

For waste facilities sited prior to RCRA and Act 64, governmental siting decisions rested with the appropriate local governmental approval bodies (e.g., city building departments and planning offices or zoning boards), which assured that standard building code, zoning requirements, and the like were met. Even in areas where zoning may have precluded siting in certain locations, zoning could be changed or variances issued. For example, Detroit was known for the "flexibility" of its ordinances (Sugrue 1996). There were typically no specific requirements pertaining to design safety, operating conditions, or public participation in siting decisions beyond those required for any other industrial facility. Due to the lack of public awareness of the risks of hazardous waste and a similar lack of development of environmental and health sciences, public and governmental involvement in siting decisions was minimal, and many facilities "functioned with an absolute minimum of technical safeguards or provisions for community input or oversight of facility management" (Rabe 1994:28). Prior to the NIMBY phenomenon and RCRA, pollution was more generally accepted as a necessary price of economic prosperity, local approvals were routine, public opposition was rare, and the legal or regulatory context allowed little democratic deliberation in siting decisions (Davy 1997).

\section{Early NIMBY Era (1970-1980)}

Although sanitary landfills offered a significant improvement over open dumping in protecting public health and the environment, growing concern over the risks of old dump sites (many that were later to be designated Superfund sites) transferred to the new landfills and other disposal facilities, such as incinerators. According to the U.S. Environmental Protection Agency (EPA), community opposition to the siting of waste facilities grew throughout the 1970 s and threatened to undermine governmental efforts to improve solid waste management (Bacow and Milkey 1982; U.S. EPA Office of Water and Waste Management 1979). Thus, public concern about waste facilities appears to have contributed to widespread growth of community organizing as environmental concern became expressed through local citizen action. This phenomenon became widely recognized and somewhat pejoratively labeled as the Not-In-My-Backyard (NIMBY) syndrome, fueled by highly visible events such as the Three-Mile Island nuclear accident of $1979 .{ }^{1}$

Despite the early emergence of mass environmental consciousness and growth in concern and citizen activism regarding solid waste facilities, accounts suggest that specific concern related to hazardous waste did not develop until around the time of Love Canal. These concerns

1. The apparent parochial nature of NIMBY does not suggest that participants in NIMBY campaigns all view the siting of facilities in other communities besides their own as acceptable. The term NIMBY is used here mainly for convenience to refer to the recent historical period in which vigorous opposition has been prevalent. NIMBY groups have grown in their sophistication and understanding of the broad context of hazardous waste problems (Szasz 1994). Some groups redefine the problem of "where to put it" by advocating, instead, for more comprehensive solutions such as source reduction and recycling (Bryant 1995). 
centered around potential health risks, the impact on property values, the inability to keep out other undesirable land uses, and overall declines in the quality of life in a host community (Edelstein 1988). Environmental public opinion surveys by the EPA in 1973 and by the Council on Environmental Quality and Resources for the Future in 1980 show a shift in attitudes during the 1970s from disinterest and acceptance to extreme concern and opposition in regard to the local placement of hazardous waste facilities (Lindell and Earle 1983). Thus, in the late 1970s, public environmental concern over hazardous waste appears to have been increasing.

In the late 1970s and early 1980s, public concern about hazardous waste and grassroots organizing against new facility siting was generated by several well-publicized and controversial cases such as those in Love Canal, New York, and in Times Beach, Missouri (Kasperson 1986). Peter M. Sandman (1985) asserts that prior to Love Canal "citizens were not very involved in, nor knowledgeable about, the siting of landfills and other hazardous waste disposal practices" (p. 439). The significance of Love Canal in catapulting public awareness (and fear) about hazardous waste does not mean that concern did not exist beforehand (Morell and Magorian 1982; U.S. EPA Office of Water and Waste Management 1979). ${ }^{2}$ However, what distinguishes the early 1970s from the late 1970s and, more so, from the early 1980s is the extent of social embeddedness of hazardous waste concern. Andrew Szasz (1994) explains that

As recently as 1976, "toxic waste" was not yet a well-formed social issue. There was no clear public opinion concerning it, no crystallized mass perception that it is a serious threat to people's health. Hazardous waste became a true mass issue between 1978 and 1980, when sustained media coverage made Love Canal and toxic waste household words. By 1980, the American public feared toxic waste as much as it feared nuclear power after Three Mile Island. (p. 5)

Thus, any public opposition to hazardous waste facilities that existed in the early-NIMBY era might have related more to the type of facility. Local opposition to hazardous waste landfills and incinerators might have stemmed from their being similar technologies to familiar solid waste management facilities, rather than the hazardous wastes themselves. But that would soon change.

\section{Post-Love Canal Era (Post-1980)}

Love Canal is a town near Niagara Falls where a residential neighborhood had been built on hazardous wastes dumped by a chemical company and covered with a thin layer of soil. Because of growing health concerns among residents, Lois Gibbs, a mother and housewife, led a lengthy campaign that captured the national spotlight. Her efforts eventually led to government action culminating in a federal buy-out of homes, President Carter visiting the site, and Congress enacting the "Superfund ACt" (see Gibbs 1982; Levine 1982). Love Canal heightened public fears that other communities were also unknowingly at risk of exposure to hazardous wastes and, more importantly, added new fuel to the NIMBY phenomenon.

According to Szasz (1994), public opposition to the siting of hazardous waste facilities was "sporadic and isolated" prior to Love Canal but became widespread and vigorous afterward. Those who share this view note that public opposition grew steadily after the late 1970s and early 1980s (Mazmanian and Morell 1994). Studies of local reactions to hazardous waste sites document the emergence of increasing numbers of community groups organized around hazardous waste issues in the early 1980s (Freudenberg 1984; Quarantelli 1989).

2. The U.S. EPA Office of Waste and Waste Management (1979) report, produced by Centaur Associates, provides examples of successful public opposition from early 1970s, including the IT Corporation facility in Brentwood, California; Padre Juan facility in Ventura County, California; and Resource Recovery Corporation in Pasco, Washington. Other unsuccessful campaigns included Wes-Con in Grandview and Bruneau, Idaho; and Calabasas, in Los Angeles, California. The vast majority of cases ( 16 of 21 ) met substantial public opposition in the late 1970 s. 
Concern about hazardous wastes paralleled that of pesticides and other forms of toxic contamination (Brown 1981). For example, in Michigan, contamination of cattle feed with a flame retardant (PBB) heightened concerns about toxic chemicals and food safety in the late 1970s and early 1980s (Reich 1991). In 1984 came news coverage of the Union Carbide (now part of Dow Chemical) factory accident in Bhopal, India, which led to community right-toknow provisions of Superfund Amendments and Reauthorization Act of 1986 (i.e., creation of the Toxic Release Inventory [TRI]).

The growth of groups organized around toxics issues was so sudden and dramatic that a popular social movement with a formal infrastructure developed (Cable and Benson 1993). The emergence of an anti-toxics movement in many middle- and working-class neighborhoods reflected a change in societal views regarding the role of citizen involvement in siting decisions (Portney 1991b). The expansion of the movement is evidenced not only by the explosive growth in the number of grassroots groups during the 1980s, but also by national networks and international organizations such as the Citizen's Clearinghouse for Hazardous Waste (recently renamed the Center for Health, Environment, and Justice), the now-defunct National Toxics Campaign, and Greenpeace (Gottlieb 1993). Dorceta E. Taylor (1998) reports that, although localized opposition existed in the 1970s, throughout the 1980s grassroots organizations increased in number by over three-fold and grew in sophistication (see also Davy 1997).

Various accounts indicate that political mobilization around hazardous waste siting proposals from the 1970 s to the 1990 s progressively moved from white middle-class, to white working-class, to minority communities (Hurley 1995; Morrison 1986; Taylor 1993, 1997). In fact, surveys of citizens' groups from the early 1980s did not report involvement of minority and low-income populations in opposition campaigns, but noted participation primarily from the white-collar middle class and sometimes the "working class" (Freudenberg 1984; Quarantelli 1989). Nevertheless, mobilization in communities of people of color in the late $1970 \mathrm{~s}$ and early 1980s has been documented, such as the widely publicized Warren County protests in North Carolina. However, the emergence of a coherent grassroots people of color movement (i.e., the environmental justice movement) does not appear to have occurred until the late 1980s and early 1990s (Taylor 2000), suggesting that minority and poor communities were initially politically vulnerable to waste facility sitings.

The impact of public opposition has been significant, especially regarding the siting of new hazardous waste facilities (Dinkins 1995; Freudenberg and Steinsapir 1991). In the 1980s, some analysts considered public opposition "the single most critical factor in developing new hazardous waste management facilities" (Furuseth 1989:358; see also Daly and Vitaliano 1987). The role of public opposition in unsuccessful siting proposals is well-documented (O'Hare, Bacow, and Sanderson 1983; Rabe 1994). The difficulty of siting new facilities in the face of nearly universal public opposition was cited as evidence of the failure of RCRA (Mazmanian and Morell 1994) and prompted calls for new approaches to siting (NGA 1981; Rabe 1994). Thus, the historic growth of public concern about hazardous waste and resulting growth in grassroots activism has changed fundamentally the sociocultural context in which facility siting occurs.

There are some important implications regarding (1) the steady and increasing environmental concern in response to increasing recognition of the seriousness of environmental problems, and (2) the explosive growth of citizen opposition to siting of environmental hazards, which appeared to have occurred relatively late in minority and working-class communities. These developments suggest that facility siting increasingly followed the path of least resistance throughout the 1970 s and 1980s. As middle-class, upper-class, and (later) workingclass communities became involved in citizen opposition groups, new facilities were increasingly likely to be deflected or directed to minority and low-income neighborhoods and communities, which were seen as the paths of least resistance due to their need for jobs and their political vulnerability associated with limited access to resources and allies in government 
(Bullard and Wright 1987). Because the environmental justice movement did not develop in earnest until the 1990s (see Taylor 2000), siting in minority and low-income communities may have increased throughout the 1970s and 1980s. Although mobilization of people of color has been significant in the 1990s, with the subsequent prominence of "success stories," their ability to resist unwanted facilities appears limited (Cole and Foster 2001; Hurwitz and Sullivan 2001; Moss 2001), suggesting that disparate siting persisted in the 1990s, though perhaps to a lesser degree.

\section{The Legal Context of Siting}

Public environmental concern also resulted in RCRA of 1976, the Hazardous and Solid Waste Amendments (HSWA) of 1984, and corresponding state legislation (Davis 1993). These laws fundamentally altered the playing field of siting contestation, particularly in the postLove Canal era when the laws took effect. We argue below that these changes in the legal and regulatory context of siting, by changing the dynamics of NIMBY-ism, further contributed to racial and socioeconomic siting disparities. We explain how siting laws served as an additional factor to encourage sitings to follow the path of least resistance by shifting authority from the local level to state and federal agencies. By shaping the political opportunity structure for public participation in siting decisions (Tarrow 1996), thereby leading to discriminatory outcomes, these institutional arrangements constitute an indirect form of institutional discrimination.

In enacting RCRA and HSWA, Congress sought for states, rather than the EPA, to administer their own hazardous waste programs. States were encouraged to pass their own legislation modeled after RCRA and to develop programs at least as stringent as the EPA's. Since passage of RCRA and Michigan's corresponding legislation, Act 64, decision-making authority in Michigan shifted from local government to the Michigan Department of Environmental Quality (DEQ). ${ }^{3}$ Local government authority under Act 64 is minimal, and merely consists of verifying that siting proposals comply with local zoning. At the same time, Act 64 gives preemptive decision-making authority to the DEQ to override local opposition to siting. This authority also exists in the majority of other states managing RCRA programs (Rabe 1994).

State siting decisions are made through permitting systems prescribed under RCRA. The purpose of permitting programs is to ensure government oversight and protection of human health and the environment in the construction, operation, and closure of facilities. In Michigan, waste facility developers must obtain a permit from the DEQ before construction can begin. Although developers can be denied a permit, the DEQ is obligated to approve a permit if a proposal meets legal and technical requirements (Davy 1997). Prior to issuance of a final permit, the agency issues a draft permit, which starts a 45 -day public comment period. In Michigan, if a public hearing is requested (they are not required), a Site Review Board oversees them and subsequently advises the DEQ (Fletcher 2003). The draft permit signals imminent state approval provided that no "substantial new questions concerning the permit are raised" (U.S. EPA Office of Solid Waste 1990:III-79). Thus, public participation in siting decisions under RCRA occurs essentially after the decision has been made (Cole and Foster 2001; Kraft and Kraut 1988). Nevertheless, the provisions provide limited access points for the public to influence final permitting decisions, and these changes and state pre-emption alter the political opportunity structure for collective action in proposed host communities (McAdam 1982).

Public participation rules allow certain communities to delay or curtail the siting process. Administrative and legal challenges at the state and federal levels, and even local zoning dis-

3. This state agency was created in 1996 as a result of a reorganization of the Department of Natural Resources (DNR). Functions related to Act 64 that were previously carried out by the DNR are now performed by the DEQ. To avoid confusion, the subsequent discussion refers only to the DEQ. 
putes, may also stall the process, thereby encouraging facility sponsors to withdraw their applications and to seek more receptive locations (Cerrell Associates, Inc. 1984; Daly and Vitaliano 1987). For facilities such as incinerators that also must obtain Clean Air Act (CAA) permits, citizen groups may file CAA appeals or law suits. However, bringing such challenges or delaying permit approvals by taking advantage of the public participation provisions of Act 64, RCRA, or other environmental laws requires considerable technical, legal, and financial resources that often are available only to affluent, politically well-connected communities. This policy environment, in disadvantaging minority and low-income communities and leading to disparate outcomes, is a form of indirect institutional discrimination (Feagin and Feagin 1986; Lake 1996; Stretesky and Hogan 1998). In fact, Thomas H. Fletcher (2003) documents affluent white communities' effective use of delay strategies to oppose hazardous waste facility siting in Michigan during the 1980s. However, less empowered communities tend to lack the political clout and resources needed to mount effective public opposition campaigns (Hurwitz and Sullivan 2001). In fact, evidence such as a report commissioned by the California Waste Management Board, entitled "Political Difficulties Facing Waste-to-Energy Conversion Plant Siting," indicates that opposition from low-income and minority neighborhoods might be less likely than from other areas (Cerrell Associates 1984; Portney 1991a).

In summary, we posit that a historical convergence of several interacting factors has contributed to disparate siting in recent decades. These developments include the growth of public concern about hazardous waste, laws to manage it, growth in local opposition to the placement of it, as well as concern about the failure to successfully site new facilities. Changes in the historical context of siting in the 1970s and 1980s contributed significantly to sociopolitical conditions in which the siting of new waste facilities followed the path of least resistance that allowed patterns of disparate siting of hazardous waste facilities during the early NIMBY era (in the 1970s). Conversely, facilities sited in the pre-NIMBY/pre-RCRA era (prior to 1970) would not necessarily have been sited disproportionately in areas least able to resist them. Furthermore, the consequences of new siting laws and policies favoring affluent communities, along with the progressive growth of environmental concern and NIMBY behaviors ignited by public fears about hazardous waste in the wake of Love Canal, suggest that disparate siting has been more prevalent and severe in the 1980s than in the 1970 s.

\section{Temporal Patterns Revealed by Previous Studies}

Although not explicitly considering the role of historical context, at least six empirical studies have examined the past demographics of hazardous waste sites to determine whether minorities or low-income persons were overrepresented, relative to the wider community, in areas near these facilities around the time of siting (Been 1994; Been and Gupta 1997; Hamilton 1993; Hurley 1997; Oakes et al. 1996; Pastor et al. 2001). The temporal spans examined by these studies vary considerably, as do the methodologies employed. For example, all but two of the studies essentially examined individual host census tracts, zip codes, townships, or counties, and thus did not necessarily geographically standardize the host areas into consistent areas over time or among facilities (Mohai and Saha 2003). Despite these limitations, the findings can be used to assess temporal patterns in disparate siting. This is accomplished by examining siting disparities in the pre-NIMBY/pre-RCRA, early NIMBY, and post-Love-Canal eras as delineated above.

Vicki Been (1994) conducted two longitudinal studies that were extensions of a 1983 U.S. General Accounting Office (GAO) study of four hazardous waste landfills in the Southeast and Bullard's 1983 study of ten municipal waste facilities and mini-incinerators in the Houston area (Harris County, Texas). Three of four facilities examined in the GAO study (U.S. GAO 1983) sited in neighborhoods with disproportionately high percentages of African Americans were sited in the 1970s. Of the 10 facilities from the Bullard study, two were sited 
in the 1950 s and the remaining eight in the 1970s. Been found five of the eight facilities sited in the 1970s were sited disproportionately with respect to race. None of the facilities sited in the pre-NIMBY/pre-RCRA era (pre-1970) evidenced disparate siting.

Similarly, in a national study, James T. Hamilton (1993) found minority percentages to be a positive predictor and mean housing values to be a negative predictor of counties that received new commercial hazardous waste facilities sited in the 1970s. In a more refined zip code area study, Hamilton (1995) found that facilities that expanded their capacity between 1987 and 1992 were disproportionately located in zip codes with higher percentages of minorities, lower housing values, and, to a lesser extent, lower incomes. In both studies, Hamilton's multivariate analyses showed an independent and significant effect (as predicted) relative to measures of public opposition. Although expansion plans are different than new sitings, Hamilton's findings are consistent with the supposition that the emergence of vigorous public opposition influenced siting decisions in the early-NIMBY and post-Love-Canal eras.

Andrew Hurley (1997) used census tracts within one mile of 56 hazardous waste sites in St. Louis, Missouri. The sites included abandoned toxic waste sites, waste recycling facilities, and other facilities that posed known health risks. A distinct historical pattern was found. Prior to 1975, African-Americans were underrepresented or proportionally represented in hazardous waste tracts compared to the metropolitan area, but after 1975, waste sites were located in predominantly African-American neighborhoods. Pastor and associates (2001) examined census tracts within one-quarter mile and one mile of 38 high-capacity hazardous waste facilities sited in the 1970s and 1980s in Los Angeles County. These host neighborhood tracts had significantly higher minority percentages (of both African Americans and Latinos) and lower incomes, housing values, and educational attainment levels prior to siting than other tracts in the county. Both Hurley (1997) and Pastor and associates (2001) show siting disparities in the early-NIMBY and post-Love-Canal eras.

Social and Demographic Research Institute (SADRI) researchers at the University of Massachusetts (Oakes et al. 1996) conducted a national study of commercial hazardous waste facilities sited in the 1960s, 1970s, and 1980s. The SADRI researchers limited their analysis to metropolitan areas with at least one facility and examined socioeconomic and housing conditions during the decade of siting. They found tracts with facilities did not have significantly higher minority percentages, poverty rates, or housing values than tracts without facilities in "areas with significant industrial employment" (Oakes et al. 1996:137). In a previous analysis of the same facilities, SADRI researchers compared host tracts to census tracts without facilities, regardless of levels of industrial and manufacturing employment (Anderson, Anderton, and Oakes 1994). As in the subsequent study, they found no significant differences in minority percentages or poverty rates, but they did find significant housing value disparities for facilities sited in the 1970s and 1980s as well as differences in levels of industrial and manufacturing employment.

Vicki Been and Francis Gupta (1997) conducted another national study that made comparisons using single host tracts but a slightly different universe of commercial hazardous waste facilities than SADRI. Been and Gupta found race, poverty, and housing disparities in the early-NIMBY era, and poverty and housing disparities in the post-Love-Canal era (see Table 1). However, they did not examine siting disparities in the pre-NIMBY/pre-RCRA era.

Another study that used counties and incorporated areas as the unit of analysis examined the location of 73 facilities on the EPA's Toxic Release Inventory sited in South Carolina from the 1930s through the 1980s (Mitchell et al. 1999). In separately examining urban, suburban, and rural areas, compared to overall state averages, Mitchell and associates (1999) found that host areas did not have significantly higher minority percentages, regardless of the decade sited. Host areas of rural facilities sited in the 1970s and 1980s did, however, exhibit disproportionately lower income levels.

Table 1 summarizes the results of this review of previous studies. Table 1 shows that racial, socioeconomic, and housing disparities at the time of siting have not been in evidence 


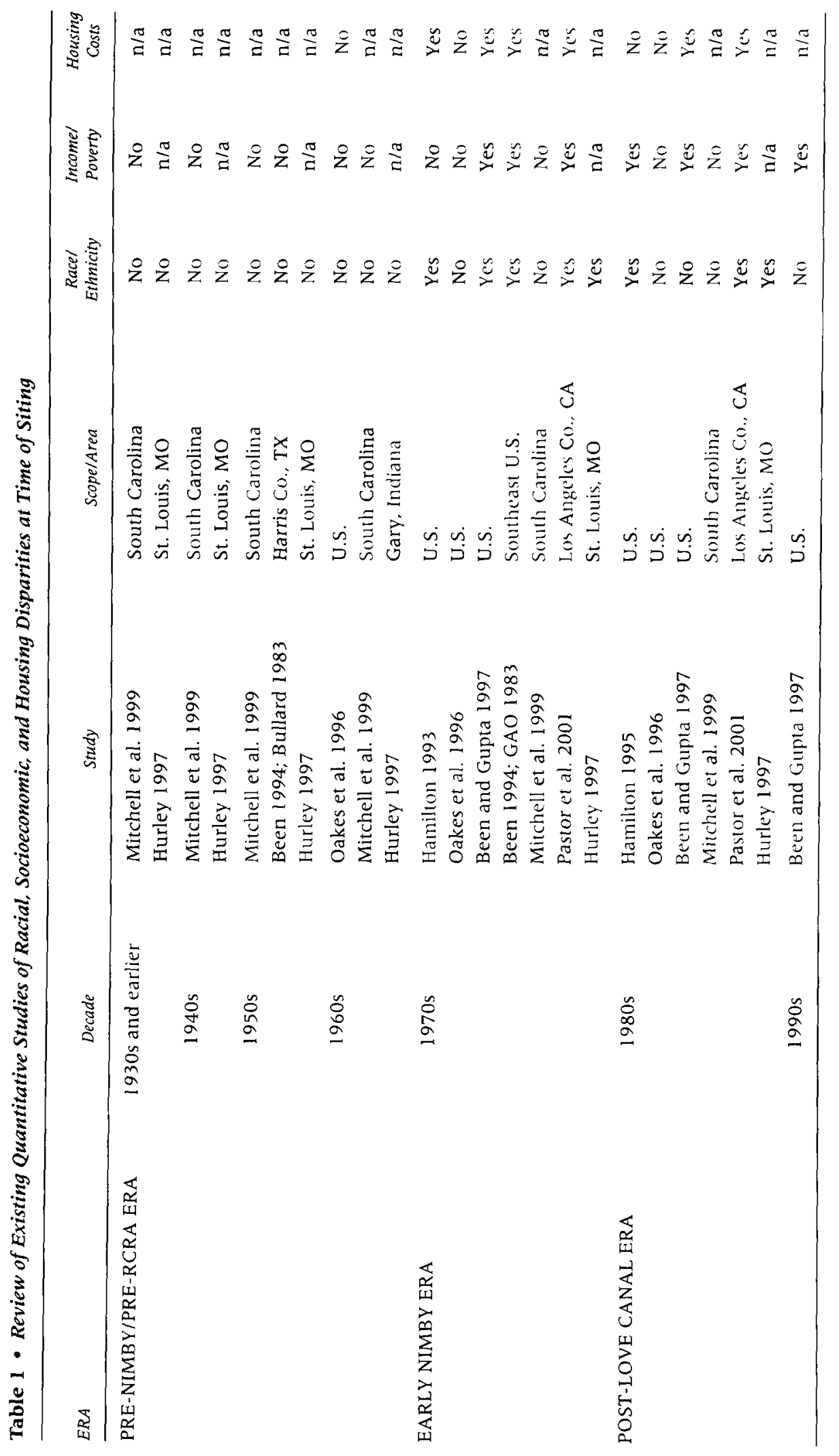


for noxious facilities sited in the pre-NIMBY/pre-RCRA era. However, in the early-NIMBY era the phenomenon appears in national-, regional-, county-, and city-level studies. Although disparities have also been found for facilities sited in the post-Love Canal era, the results appear to be less robust. Nevertheless, despite the methodological variations, a clear pattern is evident. Siting disparities appear subsequent to the emergence of widespread public environmental concerns, the concomitant rise of public opposition to waste facility siting, and changes in the policy environment of siting.

\section{Temporal Analysis of TSDF Siting in Michigan}

A more purposeful assessment of the importance of historical context to the incidence of disparate siting was conducted by examining commercial hazardous waste treatment, storage, and disposal facilities (TSDFs) sited in Michigan from the 1950s through the 1980s. We tested the hypothesis that discriminatory siting patterns did not exist for facilities sited in the pre-NIMBY/pre-RCRA era (pre-1970), but that such patterns emerged in the early NIMBY era (1970s), and increased in severity in the post-Love Canal era (post-1980).

\section{Methods}

Siting conditions were examined for 23 commercial hazardous waste TSDFs operating in Michigan in 1989. The TSDFs were identified from lists obtained from the EPA Resource Conservation and Recovery Act Information System (RCRIS) under a Freedom of Information Act request. The TSDF names and locations from RCRIS were compared to lists obtained from the Michigan Department of Natural Resources (DNR). Opening dates were either obtained from or confirmed by the DNR (Sliver 1993). The TSDFs were sited throughout the state in both metropolitan and non-metropolitan areas. Appendix A lists the geographic locations and current status of the facilities, and shows that some facilities have ceased operations since 1989. ${ }^{4}$ No new commercial TSDFs have been sited from 1989 to the time of our analysis.

The locations of facilities were digitally mapped by making site visits and using Topographically Integrated Graphic Encoding and Referencing System (TIGER) files and Geographic Information Systems software (ArcView GIS v. 3.2). This was accomplished by using the street layer of the TIGER files as a guide (GeoLytics Inc. 1999; Wessex Inc. 1995). Standardized host neighborhood areas were created with circular "buffers" of a 1.0-mile radius centered at the TSDF locations, and demographic and housing characteristics of these areas were estimated through area-weighting procedures described below. ${ }^{5}$ Delineating consistently sized circular host neighborhood areas served to control for proximity between the TSDFs and nearby populations and surmounted the difficulties of managing census tract boundary changes across multiple decades. For 1950, 1960, and 1970, high quality digitized census tracts were not available. Therefore, these were created by using printed maps as a guide and by "dissolving" the boundaries of sets of 1990 census blocks such that digital shapes produced corresponded to each of the 1950, 1960, and 1970 tracts. In some cases, it was necessary to adjust vertices of the 1990 blocks to correspond precisely to 1950,1960 , or 1970 tract boundaries. For 1980 and 1990, commercially available digitized block groups were used (GeoLytics Inc. 1998). These smaller constituent units of census tracts allowed more accurate estimation of population and housing characteristics in circular host-neighborhood areas. Block groups were not used for earlier censuses because data were not sufficiently reported at that level.

4. Three other TSDFs were excluded from the analyses because they were sited at the same location as existing facilities. These TSDFs were not treated as separate sitings, since they were essentially on-site expansions.

5. Circular areas within 2.0 miles were also examined, but the results were not substantially different than those for the 1.0-mile host neighborhoods. Therefore, the results for the 2.0 -mile areas are not reported, but can be requested from the authors. 
To estimate the demographic composition of host neighborhoods, 1.0-mile radius circular buffers were "intersected" with the digitized census tracts or block groups corresponding to the census immediately preceding and following siting, using the Xtools extension for ArcView GIS (v. 3.2) and a Lambert's Conformal Conic Projection. ${ }^{6}$ The percentage of each tract's (or block group's) area within the buffers was computed, and raw census data were weighted according to the proportion of area within each circle. For example, demographic and housing data for blocks groups 10 or 50 percent within the circle were weighted (multiplied) by 0.10 and 0.50 . Thus, if a block group had a population of 3.000 and was 30 percent within the 1.0-mile buffer, its contribution to the population of the 1.0 -mile host neighborhoods would be 900 . If an entire tract or block group was contained within the buffer, then a weighting factor of 100 percent was used (i.e., the demographic and housing characteristics for the entire tract or block group were used). Using this area-weighting method, raw data for all 1950, 1960, and 1970 tracts, and 1980 and 1990 block groups that were completely or partially intersected by the 1.0 -mile circles were aggregated. These values were used to calculate percentages and means for host neighborhoods (see Appendix B). ${ }^{7}$

Some areas within the circular buffers were not "tracted" because they were not designated by the Census Bureau as census tracts. For areas not covered by tracts, the same areaweighting procedures were applied to Minor Civil Divisions (MCDs), which are the primary incorporated and unincorporated political divisions of a county, including cities, towns, and townships. On average, MCDs are larger than census tracts, but smaller than counties. Areaweighted MCD data for untracted areas within circular buffers were aggregated with those of tracted areas to compute estimated population and housing characteristics of all areas (tracted and untracted) within a 1.0-mile radius. These steps were required for three facilities located in or near untracted areas-one sited in the 1970s and two sited in the 1980s.

The area-weighting method was employed to test two basic propositions: (1) disparate siting was less prevalent and severe prior to 1970 , and (2) the severity of disparate siting (i.e., the magnitude of racial, socioeconomic, and housing disparities) were greater for TSDFs sited in the 1980s than for TSDFs sited in the 1970s. Racial, socioeconomic, and housing disparities were assessed by examining demographic conditions at or near the time of siting to determine whether disparate siting occurred. Socioeconomic conditions in host neighborhoods were assessed by examining mean family incomes, poverty rates, and employment variables such as unemployment rates and labor force participation rates. ${ }^{8}$ These data also served as an indicator of household- and neighborhood-level economic conditions. Housing disparities were assessed by examining mean owner-occupied housing values, homeownership rates, and housing vacancy rates. In addition, changes in the size of the housing stock and new residential housing construction rates were examined (see Appendix B for a list of data sources and construction of the variables). These data provided insights into neighborhood investment, housing quality and demand, shifts in residential land use patterns, and the overall economic vitality of host neighborhoods. These analyses were done separately for TSDFs sited in each decade before 1970 and after 1970.

Because census data are reported in ten-year intervals corresponding to the beginning of each decade, it was only possible to assess demographic conditions at the exact time of siting for those facilities that were sited at the turn of a decade (i.e., 1950, 1960, 1970, etc.). Although it could be argued that decennial data might be appropriately used for facilities

6. See Oregon Department of Forestry (2003) for documentation about Xtools.

7. This method is becoming widely accepted. Other studies that have employed this type of technique include Chakraborty and Armstrong 1997; Glickman 1994; Glickman, Golding, and Hersh 1995; Hamilton and Viscusi 1999; Mohai and Saha 2003; Sheppard et al. 1999; and U.S. GAO 1995.

8. Reliable poverty rates were not available for the 1950 and 1960 censuses and thus could not be used to assess socioeconomic disparities for TSDFs sited in the 1950s and 1960s. However, for TSDFs sited after 1970, family poverty rates were available. Educational attainment levels were also examined for TSDFs sited in all decades, but their analysis did not alter the basic conclusions. These data, therefore, are not reported. 
sited within a year or two before or after a census date, facilities sited in the middle of the decade would pose a problem in determining from which census data should be considered. The approach taken was to examine conditions for the census immediately preceding siting and the census immediately following siting. By doing so, demographic and housing conditions at or near the time of siting were assessed. For example, if a facility was sited in 1962 or 1965 , then data from the 1960 and 1970 censuses were used. If disparities were noted in the location in both 1960 and 1970, then it could be reasonably assumed that disparities existed at the time of siting, since it would be highly unlikely that the disparities in 1960 would disappear in 1962 or 1965 and then reappear in 1970.

Disparities were assessed by comparing the demographic and housing conditions in 1.0mile host neighborhoods to all areas beyond 1.0 mile in the host metropolitan areas and nonmetropolitan host counties. Alternate assessments were made using the entire State of Michigan as the comparison area, but these data were not reported for a few reasons. First, many areas in Michigan, especially remote regions, were likely not suitable for siting TSDFs because, for example, they were located far from the centers of hazardous waste production and lacked necessary transportation infrastructures. These areas are not appropriate to include in the comparison area when the objective is to assess demographic and housing disparities between areas that reasonably could have received TSDFs. Second, the entire state has lower minority percentages and higher percentages of persons of low socioeconomic status than host metropolitan areas and non-metropolitan host counties, making the likelihood of finding racial and socioeconomic disparities greater. Thus, the most conservative comparison area, least likely to yield disparities, was used.

\section{Results}

Two facilities were sited in the 1950s, five in the 1960s, eight in the 1970s, and eight in the 1980s (see Appendix A). To determine whether historical context has influenced siting as hypothesized, we first consider TSDFs sited before 1970 .

Pre-NIMBY and Pre-RCRA Era Sitings (Prior to 1970). Racial, socioeconomic, and housing disparities at the time of siting were assessed for Michigan TSDFs sited in the 1950 s and 1960 s, prior to the time during which significant changes occurred in the sociocultural and legal context of siting. Table 2 shows demographic and housing data in the censuses before and after siting for TSDFs sited in the 1950s. These TSDFs were sited in the Detroit metropolitan area, which at the time included Wayne, Oakland, and Macomb counties. Table 2 shows that during the decade of siting, the total population in 1.0-mile host neighborhoods of TSDFs sited in the 1950 s decreased slightly (about 5 percent) from 43,209 to 41,072. The relatively high population density indicates that these TSDFs were located in or near residential areas in urbanized areas of metropolitan Detroit.

Table 2 also shows that host neighborhoods of TSDFs sited in the 1950s were nearly entirely white. The percentage of nonwhites in the 1.0-mile host neighborhoods was less than 1 percent in both 1950 and 1960, while areas beyond 1.0 mile in the Detroit metropolitan area were 12 percent and 15 percent nonwhite in 1950 and 1960 , respectively. ${ }^{9}$ Because TSDFs that were classified as being sited in the 1950 s for this study were sited in 1948 and 1952, the 1950 Census data corresponds to conditions closest to the time of siting. Regardless,

9. Nonwhites are nearly entirely African-American, but include all persons who did not identify as white on the race question of census questionnaires. Therefore, nonwhites may also include Asians, Pacific Islanders, and Native Americans. Because some Hispanics, or Latinos, might identify as whites, only some Hispanics are included in the nonwhite total. However, because Hispanics were only a very small percentage of the total, nonwhite percentages would not have differed if all Hispanics could be counted among the nonwhites. Making this correction was not possible prior to the 1990 Census. 


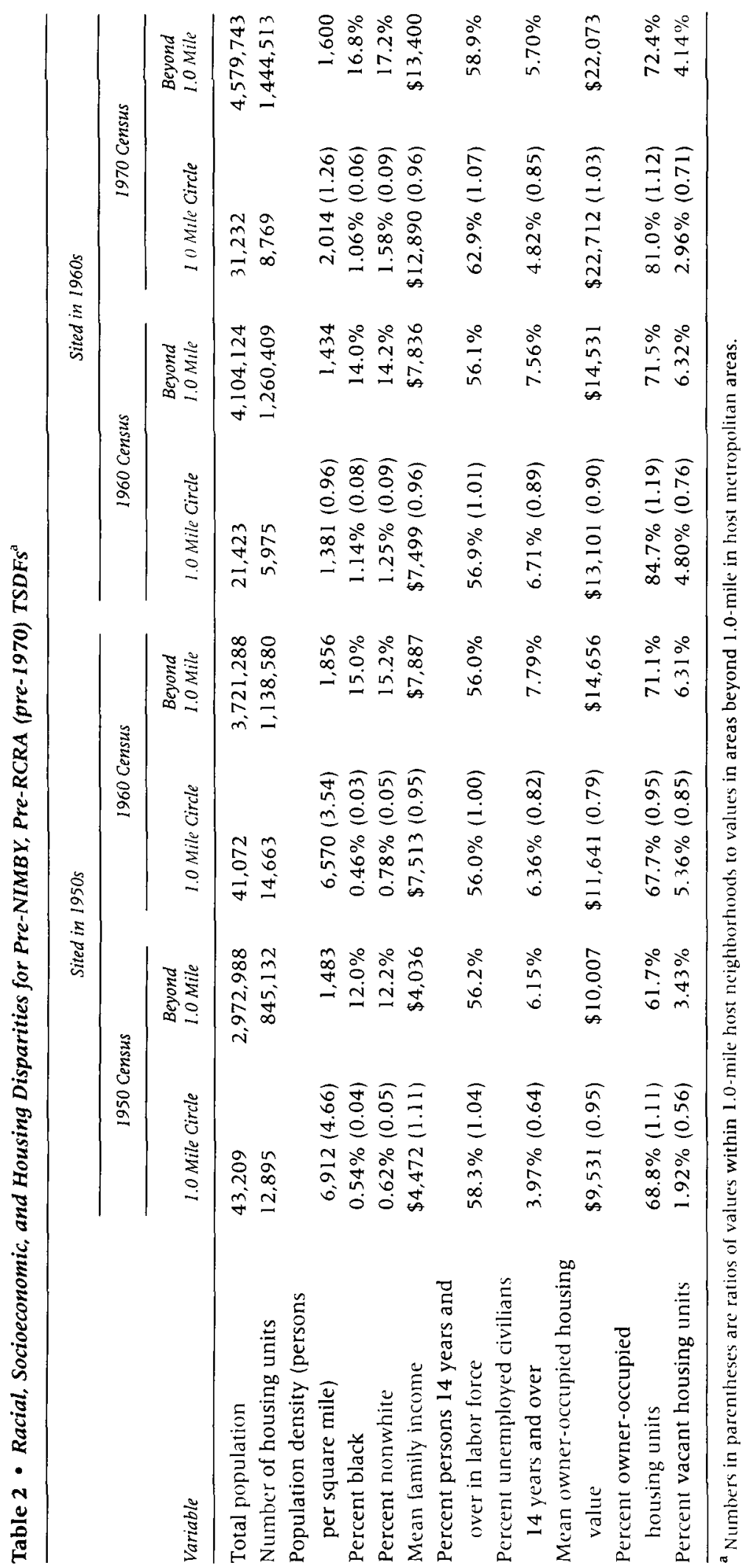


nonwhites were underrepresented in these host neighborhoods at the time of siting, and during the entire decade of siting.

In 1950, mean family income in 1.0-mile host neighborhoods was 11 percent greater than that in areas beyond 1.0 mile in the Detroit metropolitan area: $\$ 4,472$ vs. $\$ 4,036$, respectively (see Table 2 ). Thus, mean family income in host neighborhoods of TSDFs sited in the 1950s was disproportionately high at the time of siting. Employment conditions in host neighborhoods of TSDFs sited in the 1950s also appeared relatively good. In 1950, labor force participation rates in the host neighborhoods were slightly higher than those in areas beyond 1.0 mile ( 58 percent vs. 56 percent). Table 2 also shows lower civilian unemployment rates in host neighborhoods than in more distant non-host areas (4.0 percent vs. 6.2 percent). The 1960 data show that employment conditions remained robust throughout the 1950 s.

Mean housing value in host neighborhoods, however, appeared to decline relative to the comparison areas. For example, in 1950, mean owner-occupied housing value within 1.0 mile $(\$ 9,531)$ was 5 percent lower than that in areas beyond 1.0 mile $(\$ 10,007)$. However, in 1960 the mean within 1.0 mile was 21 percent lower than in the comparison areas. Although housing value was not disproportionately low at the time of siting, neighborhood changes occurred in the decade of siting that appear to have had an adverse impact on housing values. Appreciation and new home building in other parts of the county can also explain the increasing housing value disparity. Nevertheless, homeownership rates remained relatively robust throughout the 1950 s, while housing vacancy rates in host neighborhoods stayed relatively low (see Table 2 ). In addition, the number of housing units increased 14 percent, from 12,895 to 14,663 . Growth in the housing stock indicates that TSDFs sited in the 1950s were in thriving residential areas.

In fact, overall economic, employment, and housing conditions in host neighborhoods of TSDFs sited in the 1950 s appear to have been relatively good during the entire decade of siting. The only remarkable finding regarding these host neighborhoods was the extremely low representation of minorities.

Siting conditions were remarkably similar for TSDFs sited in the 1960s, all but one of which were also sited in the Detroit metropolitan area (see Appendix A). In 1960, the nonwhite percentage in 1.0-mile host neighborhoods was about 1 percent, compared to 14 percent in areas beyond 1.0 mile in the host metropolitan area (see Table 2). In 1970, the nonwhite percentage in these host neighborhoods was still less than 2 percent, while in comparison areas it was 17 percent.

In 1960 and 1970, mean family income in host neighborhoods was similar to (only 4 percent lower than) that in comparison areas. Thus, no pattern of income disparities at the time of siting could be discerned. Although mean housing value in 1960 within 1.0 mile was approximately 10 percent lower than the mean value in areas beyond 1.0 mile $(\$ 13,101 \mathrm{vs}$. $\$ 14,531)$, it rebounded by 1970 , when it was 3 percent higher $(\$ 22,712$ vs. $\$ 22.073)$. Thus, neither a strong nor consistent pattern of housing value disparities is evident. Table 2 shows that host neighborhoods of TSDFs sited in the 1960s had relatively high homeownership rates and low housing vacancy rates, indicating relatively good housing conditions in these neighborhoods. In addition, from 1960 to 1970 , the number of housing units increased 47 percent, compared to a 15 percent increase in comparison areas. These findings are generally consistent with those of TSDFs sited in the 1950s.

Employment conditions in host neighborhoods of TSDFs sited in the 1960 s were also favorable relative to the rest of the host metropolitan area. For example, Table 2 shows that labor force participation rates in 1.0-mile host neighborhoods were 57 and 63 percent in 1960 and 1970, respectively, compared to 56 and 59 percent in areas beyond 1.0 mile. Unemployment rates were also slightly lower in host neighborhoods than in comparison areas in 1960 and 1970.

Overall racial, socioeconomic, and housing conditions in host neighborhoods of TSDFS sited in the 1960s were very similar to those of TSDFs sited in the 1950s. Minorities were 
underrepresented in host neighborhoods of TSDFs sited in both decades. These facilities were sited disproportionately in non-minority or white areas. Using mean income as an indicator, overall socioeconomic status in host neighborhoods of pre-1970 TSDFs sited was comparable to those in more distant areas in the host metropolitan area. Parity in employment conditions and relatively high homeownership rates demonstrate that host neighborhoods of TSDFs sited in the 1950s and 1960s were not economically depressed. Housing vacancy rates and increases in the number of housing units also indicate relatively high housing demand. Thus, in nearly all respects, neighborhoods of TSDFs sited before 1970 appear to have been vibrant, affordable, and desirable places to live when the hazardous waste facilities were sited.

Population density data show some differences between the TSDFs sited in the $1950 \mathrm{~s}$ and 1960s. Table 2 shows a much higher population density in the decade of siting in host neighborhoods of TSDFs sited in the 1950s than those sited in the 1960 s (6,912 vs. 1,381 persons per square mile, respectively). These data are consistent with the more urban location of TSDFs sited in the 1950s (see Appendix A). Table 2 also shows that, during the 1950s, population density decreased in host neighborhoods of TSDFs sited during the 1950s, whereas population density increased rapidly during the 1960s in host neighborhoods of TSDFs sited during the 1960 s. Thus, during the decade of siting, there appear to be inherent demographic differences between host neighborhoods of TSDFs sited in the 1950s and 1960s, the former showing population decline and the latter exhibiting population growth.

These changes suggest that host neighborhoods of TSDFs sited during the 1950 s underwent a slight economic decline during the decade of siting, whereas host neighborhoods of TSDFs sited during the 1960 s did not. This conclusion is reinforced by data on rates of home ownership (i.e., the percentage of owner-occupied housing). Table 2 shows that the homeownership rate in 1.0-mile host neighborhoods of TSDFs sited in the 1950 s was greater than that in non-host areas beyond 1.0 mile in 1950 (69 percent vs. 62 percent). However, during the 1950s homeownership rate remained static in these host neighborhoods, but increased dramatically elsewhere, such that the homeownership rate became slightly lower than that in non-host areas in 1960 (68 percent vs. 71 percent). In contrast, the homeownership rate in host neighborhoods of TSDFs sited in the 1960 s was much higher ( 85 percent) and remained consistently above rates in non-host areas throughout the decade of siting (i.e., in both 1960 and 1970; see Table 2). A similar pattern can be noted with regard to mean family income changes.

Despite these differences, Michigan TSDFs sited before 1970 exhibited no consistent or strong racial, income, or housing disparities at the time of siting. However, if our proposition that historical context is important to the incidence of disparate siting is correct, then disparities will be in evidence with respect to TSDFs sited after 1970.

Early NIMBY Era Sitings (in the 1970s). Eight TSDFs were sited in Michigan during the 1970s, four in the Detroit area, three in the Grand Rapids-Muskegon-Muskegon Heights area, and one in a non-metropolitan area. Because TSDFs sited in the 1970s were located in two different metropolitan areas and a non-metropolitan county (Allegan), areas beyond 1.0 mile in the host metropolitan areas and non-metropolitan host county were used as the comparison area. For TSDFs sited in the 1970s, Metropolitan Statistical Area boundaries (MSAs) as defined in 1970 were used to ensure that comparison areas consisted of the same geographic areas for the 1970 and 1980 censuses. The Detroit MSA included, Macomb, Oakland, and Wayne counties. The Grand Rapids and Muskegon MSAs included Kent, Muskegon, and Ottawa Counties. ${ }^{10}$ For TSDFs sited in the 1980s, MSA boundaries were used as defined in 1980. This entailed adding Lapeer and St. Clair counties for the Detroit MSA and substituting a different non-metropolitan county (Alpena).

10. Livingston County was excluded from the Detroit MSA because it became part of the Ann Arbor Primary MSA (PMSA) in 1990. To be consistent, only counties in 1980 MSAs that were also part of an MSA in 1990 were used. As a result, Oceana County was excluded from the Muskegon MSA 
Table 3 shows that host neighborhoods of TSDFs sited in the 1970s had a disproportionately high percentage of nonwhites at or near the time of siting. In 1970, the nonwhite percentage in 1.0-mile host neighborhoods was 2.9 times greater than that in areas beyond 1.0 mile in the host MSAs and non-metropolitan host county (46 percent vs. 16 percent). In 1980, the nonwhite percentage within 1.0 mile was 3.4 times greater than that in areas beyond 1.0 mile ( 67 percent vs. 20 percent). Thus, large racial disparities at the time of siting are evident.

Table 3 also shows that income disparities existed at the time of siting for TSDFs sited in the 1970s. In 1970, mean family income in 1.0-mile host neighborhoods was 23 percent less than that in areas beyond 1.0 mile $(\$ 10,167$ vs. $\$ 13,289)$. In 1980 , mean family income within 1.0 mile was 35 percent less than that beyond 1.0 mile $(\$ 17,681$ vs. $\$ 27,110)$. Thus, there were not only substantial income disparities, but the magnitude of these disparities increased during the decade of siting. Table 3 shows a similar pattern for family poverty rates in 1970, which in 1.0-mile host neighborhoods were 2.0 times greater than those in the area beyond 1.0 mile ( 18 percent vs. 9.1 percent). In 1980 , the family poverty rate was 2.6 times greater ( 18 percent vs. 6.7 percent). These data show that the poverty rate in host neighborhoods of TSDFs sited in the 1970s remained static, while it decreased in comparison areas. Disparities were also found with respect to employment conditions. In 1970, the unemployment rate in host neighborhoods was 1.4 times greater than that in comparison areas (8.1 percent vs. 5.7 percent). However, by 1980 the unemployment rate was 1.8 times greater in the same host neighborhoods (20 percent vs. 11 percent). A similar pattern can be noted with respect to labor force participation rates. The above data demonstrate that socioeconomic conditions in host neighborhoods of TSDFs sited in the 1970s were disproportionately low.

These host neighborhoods exhibited housing value disparities that increased during the decade of siting. Table 3 shows that mean housing value in 1.0-mile host neighborhoods in 1970 was 37 percent less than values in areas beyond 1.0 mile $(\$ 13,767$ vs. $\$ 21,831)$. By 1980, mean housing value had become 54 percent less in host neighborhoods $(\$ 22,489$ vs. $\$ 48,961)$. The homeownership rate was also consistently lower in host neighborhoods. For example in 1970, the homeownership rate was 65 percent, compared to 73 percent in nonhost areas. In 1980, the homeownership rate in host neighborhoods declined considerably to 57 percent, while in comparison areas it had declined very slightly to 72 percent. Table 3 shows that host neighborhoods of TSDFs sited in the 1970 s also had a higher housing vacancy rate. In 1970, the vacancy rate in host neighborhoods was lower than that in nonhost areas (7.1 percent vs. 4.1 percent). In 1980, the vacancy rate in host neighborhoods was 9.1 percent, but only 4.9 percent in comparison areas. Because housing vacancy rate in host neighborhoods grew much more rapidly during the decade of siting than in non-host areas, the magnitude of disparities increased during this period.

The lower housing values, lower homeownership rates, and higher housing vacancy rates as well as worsened employment conditions indicate that household- and neighborhoodlevel economic conditions were relatively depressed in host neighborhoods at the time of siting. The depressed economic conditions in host neighborhoods of TSDFs sited in the $1970 \mathrm{~s}$ also are evidenced by the loss of population and residential housing. Table 3 shows that, from 1970 to 1980 , the population in 1.0-mile host neighborhoods declined by over 22,000 persons (18 percent). The number of housing units also declined by 3,853 (9.1 percent) during the decade of siting. These declines occurred while the population remained stable and the number of housing units increased over 16 percent in the comparison areas. This finding suggests that housing units in some residential areas were falling into disrepair and being demolished. It appears that TSDF host neighborhoods were being converted to other land uses, such as industrial, or were just outright abandoned. In fact, little new housing construction occurred in host neighborhoods of TSDFs sited during the 1970s: 6.5 percent of all housing units in 1.0-mile host neighborhoods were built during the $1970 \mathrm{~s}$, compared to nearly 20 percent of those in areas beyond 1.0 mile. The loss of housing and low rates of new housing 


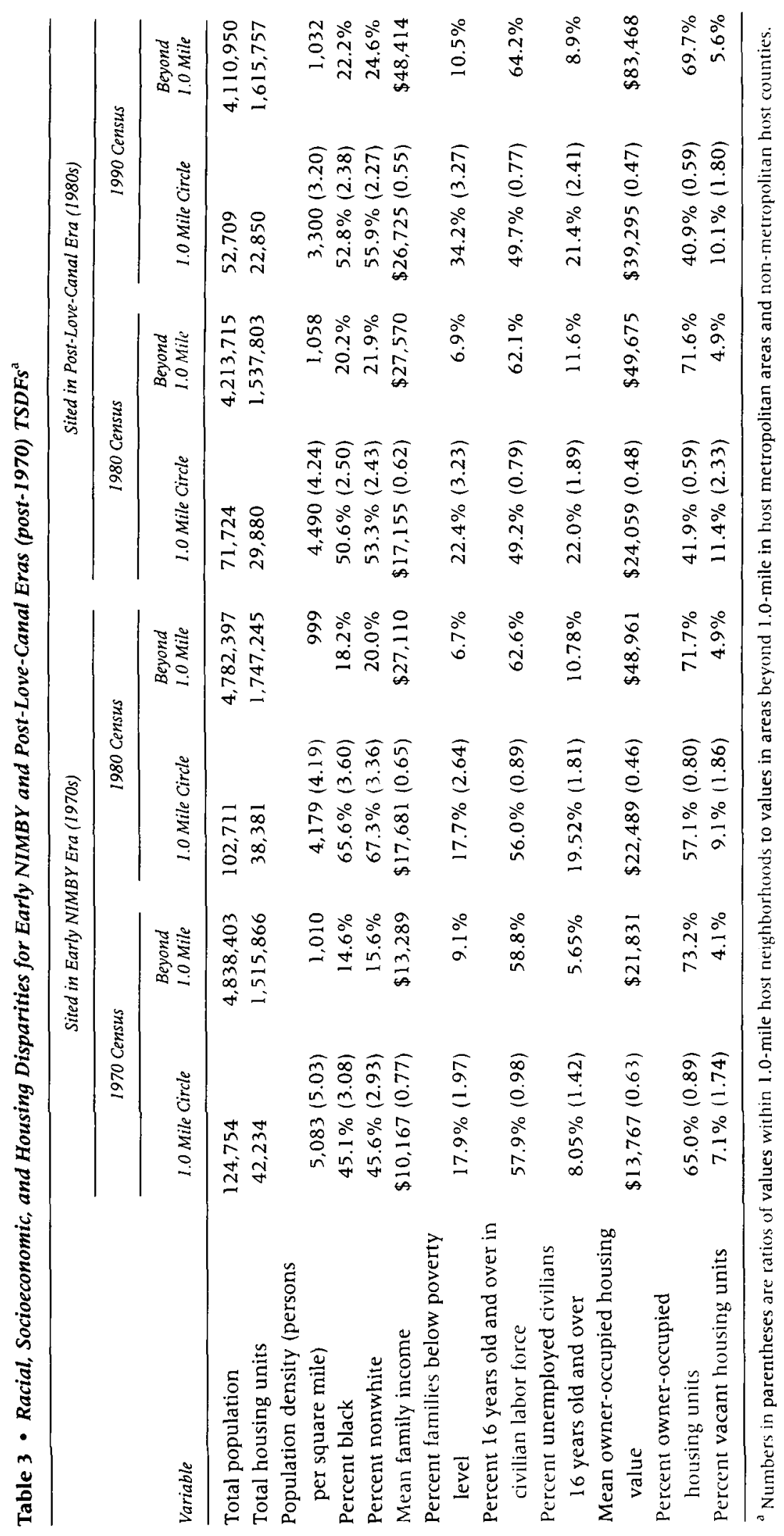


construction indicate that these host neighborhoods were undergoing residential decline in the decade of siting. Moreover, the finding of racial, socioeconomic, and housing disparities at the time of siting for TSDFs sited in the 1970s supports the hypothesis that siting disparities would be found for TSDFs sited after 1970 and the advent of mass environmental concern and the NIMBY phenomenon.

Post-Love Canal Era Sitings (in the 1980s). Racial, socioeconomic, and housing disparities were also evident at the time of siting for the eight TSDFs sited in Michigan during the 1980s. Six were sited in the Detroit metropolitan area, and five of these were sited in the City of Detroit. Two were located in the City and County of Alpena in the northeast lower peninsula of Michigan.

The nonwhite percentage in 1.0-mile host neighborhoods of TSDFs sited in the $1980 \mathrm{~s}$ was consistently higher than that in non-host areas. Table 3 shows that, in 1980, the nonwhite percentage in 1.0-mile host neighborhoods was 2.4 times that in non-host areas beyond 1.0 mile ( 53 percent vs. 22 percent). In 1990, the nonwhite percentage in these host neighborhoods was 2.3 times greater than that in comparison areas ( 56 percent vs. 25 percent). Although the nonwhite percentage increased slightly in both host neighborhoods and comparison areas during the 1980s, the magnitude of racial disparities did not increase; rather, it actually decreased slightly. These findings indicate that the minority percentage in host neighborhoods of TSDFs sited in the 1980s was not growing rapidly or disproportionately during the decade of siting, in contrast to host neighborhoods of TSDFs sited in the 1970s. In fact, racial disparities for more recent sitings appear to be slightly smaller in magnitude than for those sited in the 1970s, running contrary to the hypothesis that disparities would increase from the 1970s and 1980s. Nevertheless, the high percentage of nonwhites in host neighborhoods suggests that racial transition occurred prior to the decade of siting. These host neighborhoods were well-established African-American areas, which is consistent with the preponderance of these TSDFs being located in the City of Detroit.

Income disparities at the time of siting are also in evidence for TSDFs sited in the 1980s. Table 3 shows that in 1980 mean family income in 1.0-mile host neighborhoods was 38 percent lower than that in areas beyond 1.0 mile $(\$ 17,155$ vs. $\$ 27,570)$. In 1990 , mean income was 45 percent lower in host neighborhoods than in comparison areas $(\$ 26,725$ vs. $\$ 48,414)$. Poverty rates appear to follow a similar trend. Thus, income disparities appeared to be increasing during the decade of siting, suggesting that host neighborhoods were undergoing relative economic decline. In fact, the magnitude of these disparities was greater than that for TSDFs sited in the 1970s.

Similarly, disparities in employment conditions were greater for TSDFs sited in the 1980s. For example, unemployment rate disparities were greater for TSDFs sited in the 1980s than in the 1970s: 1.9 to 2.4 times greater in host neighborhoods of the 1980s-sited TSDFs, compared to 1.4 to 1.8 times greater for the 1970s-sited TSDFs. In both 1980 and 1990, the unemployment rate for 1980 s-sited TSDFs exceeded 20 percent. In addition, disparities in the labor force participation rate were considerably greater for TSDFs sited in the 1980s than for TSDFs sited in the 1970s. In fact, the labor force participation rates for censuses immediately preceding and following siting in host neighborhoods of 1980s sitings (49-50 percent) were much lower than those of 1970 s sitings (56-58 percent). Thus, socioeconomic conditions in host neighborhoods of TSDFs sited in the more recent decade were less favorable than those in host neighborhoods of TSDFs sited in the 1970s. These results provide additional evidence that the magnitude of disparities at the time of siting has increased over time, despite the aforementioned findings regarding racial disparities.

Table 3 also reveals housing value disparities. For example, in 1980, mean owner-occupied housing value in host neighborhoods was 52 percent less than that in areas beyond 1.0 mile $(\$ 24,059$ vs. $\$ 49,675)$. These disparities are far greater in magnitude than those of TSDFs sited in the 1970s, for which values for the pre-siting census were 37 percent lower in 
host neighborhoods. In 1990, the magnitude of housing value disparities for the 1980s TSDFs remained virtually unchanged. The homeownership rate was also relatively low. The 1980 homeownership rate in host neighborhoods was 42 percent, compared to 72 percent in nonhost areas. In 1990, these disparities persisted. The homeownership rate in host neighborhoods was 41 percent versus 71 percent in comparison areas. These homeownership rates were considerably lower than analogous pre-siting and post-siting rates for host neighborhoods of TSDFs sited in the 1970s, which were 65 percent and 57 percent in 1970 and 1980 . respectively (see Table 3 ).

The lower mean housing value and homeownership rate relative to those of TSDFs sited in the 1970s suggest that TSDFs sited in the 1980 s were located in declining residential neighborhoods with relatively low housing demand. In fact, the population in these host neighborhoods decreased more than 20 percent during the decade of siting, while population in nonhost areas decreased 2.4 percent. Housing vacancy rate data reinforce this conclusion. Table 3 shows extremely elevated vacancy rates in both 1980 and 1990 in host neighborhoods of TSDFs sited in the 1980s. In 1980, the vacancy rate of 11 percent was 2.3 times greater than the 4.9 percent rate in areas beyond 1.0 mile. Housing vacancy rate disparities can also be noted in 1990. In contrast, host neighborhoods of TSDFs sited in the 1970s had a vacancy rate of 9.1 percent in 1980 , or 1.9 times greater than areas beyond 1.0 mile. In fact, of the vacant housing units in host neighborhoods of TSDFs sited in the 1980s, 14 percent were boarded up in 1990 and, therefore, were uninhabitable.

These data suggest that many housing units had fallen into disrepair during the 1980s. Table 3 also provides evidence of the abandonment of residential housing during the decade of siting: 24 percent of the housing units within 1.0 mile of TSDFs sited in the 1980s were lost from 1980 to 1990 . This severe housing loss occurred against the backdrop of a 5.1 percent housing unit increase in the comparison areas. In contrast, 9.1 percent of housing units were lost during the decade of siting within 1.0 mile of TSDFs sited in the 1970s. This finding provides additional support for the hypothesis that TSDFs would be sited in increasingly impoverished and declining neighborhoods over time as public opinion and opposition regarding new facility siting increasingly galvanized and the policy environment of siting evolved. Overall, disparities among economic indicators increased in magnitude between the 1970s and 1980s, while the magnitude of racial disparities did not. Possible reasons are explored below.

\section{Discussion}

Models of environmental injustice tend to assume that public opposition, attitudes that drive the NIMBY phenomenon, and government and industry responses have been constant over time; therefore, they predict siting disparities regardless of the historical context of siting. However, we found evidence of disparate siting in the early NIMBY and post-Love Canal eras, but not in the pre-NIMBY/pre-RCRA era. This finding is consistent with the proposition that growth of environmental concern, public opposition, and changes in the policy environment-and thus the political opportunity structure-prompted hazardous waste facilities sitings to follow the path of least resistance. Although widespread concern about hazardous waste did not develop until the late 1970s, general public awareness in the late 1960s and early 1970s about waste facilities, pollution, and other environmental issues may have spilled over to siting of hazardous waste facilities. Following Love Canal, specific concern about hazardous waste, hazardous waste facilities, and related NIMBY behaviors expanded greatly, particularly in the 1980s when RCRA provided new opportunities for neighborhoods with high levels of political clout and technical know-how necessary to influence siting decisions. Industry, in turn, altered its site-selection strategy through the permitting process; as the antitoxic movement emerged and public opposition posed a serious threat to siting, minority and low-income neighborhoods were increasingly attractive locations (Bruelle 2000; Cerrell 
Associates, Inc. 1984; Daly and Vitaliano 1987). Thus, the basic factors driving the sociopolitical and rational choice explanations have changed dramatically over recent decades. While it is less clear how factors underlying racial discrimination explanations have changed over time, institutional discrimination may have been relatively constant in its presence, if not its exact character or causal mechanisms (see discussion below).

The increased magnitude of economic disparities from the 1970s to 1980s supports the hypothesis that the burgeoning NIMBY phenomenon and new opportunities for public participation in siting decisions, coupled with the assertion of pre-emptive state authority, increasingly encouraged disparate siting. Although the magnitude of racial siting disparities did not increase from the 1970 s to 1980 s, they remained significant. Host neighborhoods of TSDFs sited in the 1980s were predominantly African-American. Sitings in both the 1970s and 1980s exhibited signs of progressively worsening economic and housing conditions, as new commercial hazardous waste facilities were increasingly located in the deteriorating urban core of Detroit. Consequently, host neighborhoods exhibited increasingly lower housing values, lower new home construction rates, and larger and more pervasive losses of population and housing. In fact, in these recent decades, neighborhood demographic and housing changes took place prior to and during the decade of siting.

The Detroit metropolitan area includes a highly segregated central city and smaller AfricanAmerican enclaves (such as parts of the City of Pontiac), which appear to have been targeted for new TSDFs sited in the 1980s, by a process very similar to that which Laura Pulido, Steve Sidawi, and Robert O. Vos (1996) describe in detail regarding the Mobil refinery and other industry in Torrance, California. The siting of new TSDFs in older residential areas with aging and deteriorating housing occurred at a time when Detroit experienced de-industrialization and white flight, processes that further concentrated people of color and the poor in the central city (Sugrue 1996; Wilson 1992). Host neighborhoods of TSDFs sited in the 1970s underwent dramatic racial transition and economic decline during the 1970s, whereas host neighborhoods of TSDFs sited in the 1980s already had undergone such changes. By reducing neighborhood social cohesion and political capacity, as Pastor and associates (2001) also observed, demographic instability could make such neighborhoods particularly vulnerable to new facility sitings. While this last observation is consistent with sociopolitical models, racial discrimination explanations also apply.

For example, a history of industrial and residential development in the East Los Angeles area similarly notes how housing segregation and disinvestment helped to concentrate minorities in areas with the least desirable types of land uses (Pulido et al. 1996). The limited redevelopment options of blighted areas, the courting of polluting industry, and the establishment of industrial zoning in minority enclaves paved the way for siting of waste and other polluting facilities-a case of siting following the "path of most assistance" rather than the path of least resistance. Christopher Boone and Ali Modarres (1999), Robert Hersh (1995), Hurley (1995), Chad Montrie (2005), David N. Pellow (2002), and Andrew Szasz and Michael Meuser (2000) have documented similar examples of how racial segregation, economic decline, uneven redevelopment, and industrial zoning concentrated low-income populations and segregated minorities where environmental hazards were then located in Commerce, California; Pittsburgh, Pennsylvania; Gary, Indiana; Memphis, Tennessee; Chicago, Illinois; and San Jose, California, respectively. The racial disparities and increasing magnitude of disparities in economic and housing conditions associated with TSDFs sited in Michigan supports a similar conclusion. In fact, nationwide, factors increasing such vulnerability to siting were particularly virulent in the 1970s and 1980s (Jargowsky 1997; Massey and Denton 1993; Wilson 1987). Because the breadth of social forces contributing to these temporal patterns have a decidedly institutional character, disparate siting can be viewed as a form of indirect institutional discrimination.

The slight decrease in the magnitude of racial disparities in the $1980 \mathrm{~s}$ is consistent with the early emergence of the environmental justice movement and growth in the capacity of 
minority and low-income communities to oppose new facility siting effectively. However, because no new commercial hazardous waste facilities were sited in Michigan during the 1990s, the decade in which the movement came to the fore, this possibility was not assessed.

\section{Conclusions}

Our longitudinal study of disparate siting in Michigan reveals temporal patterns that correspond to historic changes in sociopolitical conditions (i.e., pubic attitudes and actions, institutional arrangements, and the policy environment of siting). Pre-NIMBY/pre-RCRA era facilities were located in economically vibrant neighborhoods with relatively good housing and employment conditions. In contrast, host neighborhoods of TSDFs sited in the early NIMBY and post-Love Canal eras exhibited progressively more depressed economic and housing conditions. Furthermore, host neighborhoods of these TSDFs, sited in the 1970s and 1980s, had increasingly severe income and poverty disparities, low housing demand, and high rates of residential housing decline at the time of siting. These findings are generally consistent with the review of previous studies of disparate siting and facility expansion plans (e.g., Hamilton 1995; Hurley 1997).

However, to firmly establish the role that historical context plays in disparate siting, more longitudinal studies are needed. These studies should examine other states and regions and the nation as a whole, as well as other types of locally unwanted land uses. If possible, they should extend their temporal scopes to before 1970, and assess effects of the environmental justice movement on siting decisions since 1990. We also suggest that future environmental justice studies, both cross-sectional and longitudinal, not assume that sociopolitical conditions and policy environment in the past were the same as they are today or that conditions in previous periods were uniform. Better understanding is also needed of how changes in the types of racial discrimination-overt and subtle, individual and institutional-have influenced siting decisions over time. Finally, we encourage greater exploration than was possible in this study of ways to integrate rational choice, sociopolitical, and racial discrimination models, for example, by further understanding how they may be mutually reinforcing, or interacting, over time (Pulido 1996).

Over the past several decades, siting decisions have occurred in a highly contested political landscape. Our findings support the argument that siting increasingly has followed the path of least resistance as a result of unprecedented growth in public environmental concern and citizen action. Institutional factors also are likely to have contributed to the historical patterns. As state and federal agencies assumed responsibility for approving siting proposals of industry, legislatively mandated permitting processes have provided new political opportunities for public involvement, both administrative and judicial. Distributional politics appear to have prevailed such that those segments of the population with fewer political, organizational, and technical resources have borne a disproportionate share of the society's environmental burdens.

Moreover, the historic patterns found in this study suggest that discriminatory siting is here to stay, given the current sociopolitical and legal terrain. As long as the most polluted and disempowered communities are seen and remain as paths of least resistance, attention to post-siting neighborhood changes that may exacerbate siting disparities might only serve as a diversion from the difficult task of addressing institutional forms of discrimination that pervade industry and governmental siting decisions. Government and industry policies that equalize the playing field and pay attention to the racial and socioeconomic composition and existing pollution burden of proposed host neighborhoods could help. Also helpful would be reform of economic development policies and practices by which local officials court or assist polluting industries in locating in already overburdened areas and overlook such areas for more benign forms of redevelopment. 


\section{Appendix}

Table A - Geographic Location and Current Operating Status for Commercial TSDFs Operating in Michigan in 1989, by Decade Opened

\begin{tabular}{|c|c|c|c|c|c|c|}
\hline \# & $\begin{array}{l}\text { Decade } \\
\text { Opened }\end{array}$ & $\begin{array}{c}\text { Closed or } \\
\text { Closing } \\
\text { as of } 2002\end{array}$ & Metropolitan Area & County Census Division (CCD) & $\begin{array}{c}\text { Urbanized } \\
\text { Area in } \\
1990\end{array}$ & $\begin{array}{c}\text { Central } \\
\text { City } \\
\text { Location }\end{array}$ \\
\hline 1 & $1950 \mathrm{~s}^{\mathrm{a}}$ & No & Detroit & Detroit & Yes & Yes \\
\hline 2 & $1950 \mathrm{~s}$ & Yes & Detroit & Dearborn & Yes & No \\
\hline 3 & $1960 \mathrm{~s}$ & No & Detroit & Van Buren Township & No & No \\
\hline 4 & $1960 \mathrm{~s}$ & No & Detroit & Romulus & Yes & No \\
\hline 5 & $1960 \mathrm{~s}$ & Yes & Detroit & Roseville & Yes & No \\
\hline 6 & $1960 \mathrm{~s}$ & No & Detroit & Brownstown Township & No & No \\
\hline 7 & $1960 \mathrm{~s}$ & No & Grand Rapids-Muskegon & Grandville & Yes & No \\
\hline 8 & $1970 \mathrm{~s}$ & No & Detroit & Detroit & Yes & Yes \\
\hline 9 & $1970 \mathrm{~s}$ & Yes & Grand Rapids-Muskegon & Grand Rapids & Yes & Yes \\
\hline 10 & $1970 \mathrm{~s}$ & Yes & Detroit & Inkster & Yes & No \\
\hline 11 & $1970 \mathrm{~s}$ & Yes & Grand Rapids-Muskegon & Muskegon Heights & Yes & No \\
\hline 12 & $1970 \mathrm{~s}$ & No & Detroit & Detroit & Yes & Yes \\
\hline 13 & $1970 \mathrm{~s}$ & No & Detroit & Van Buren Township & No & No \\
\hline 14 & $1970 \mathrm{~s}$ & No & Non-metropolitan & Plainwell & No & No \\
\hline 15 & 1970 s & No & Grand Rapids-Muskegon & Dutton & No & No \\
\hline 16 & $1980 \mathrm{~s}$ & Yes & Detroit & Detroit & Yes & Yes \\
\hline 17 & $1980 \mathrm{~s}$ & Yes & Detroit & Pontiac & Yes & No \\
\hline 18 & $1980 \mathrm{~s}$ & No & Detroit & Detroit & Yes & Yes \\
\hline 19 & $1980 \mathrm{~s}$ & No & Detroit & Detroit & Yes & Yes \\
\hline 20 & $1980 \mathrm{~s}$ & No & Non-metropolitan & Alpena & No & No \\
\hline 21 & I $980 \mathrm{~s}$ & No & Detroit & Detroit & Yes & Yes \\
\hline 22 & $1980 \mathrm{~s}$ & No & Non-metropolitan & Alpena & No & No \\
\hline 23 & $\mathrm{I} 980 \mathrm{~s}$ & Yes & Detroit & Detroit & Yes & Yes \\
\hline
\end{tabular}

Sited in 1948, but treated as 1950 s siting. 


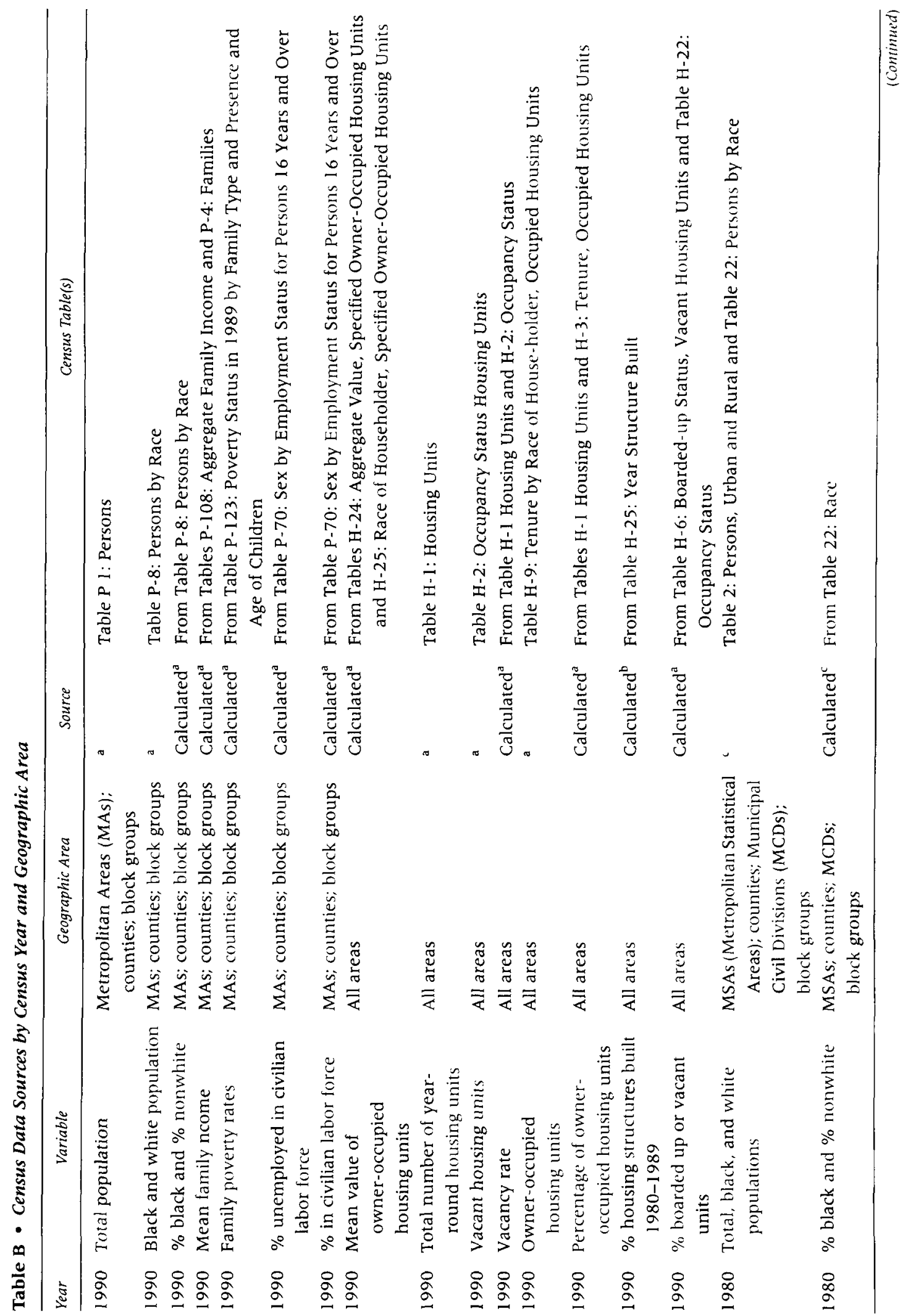




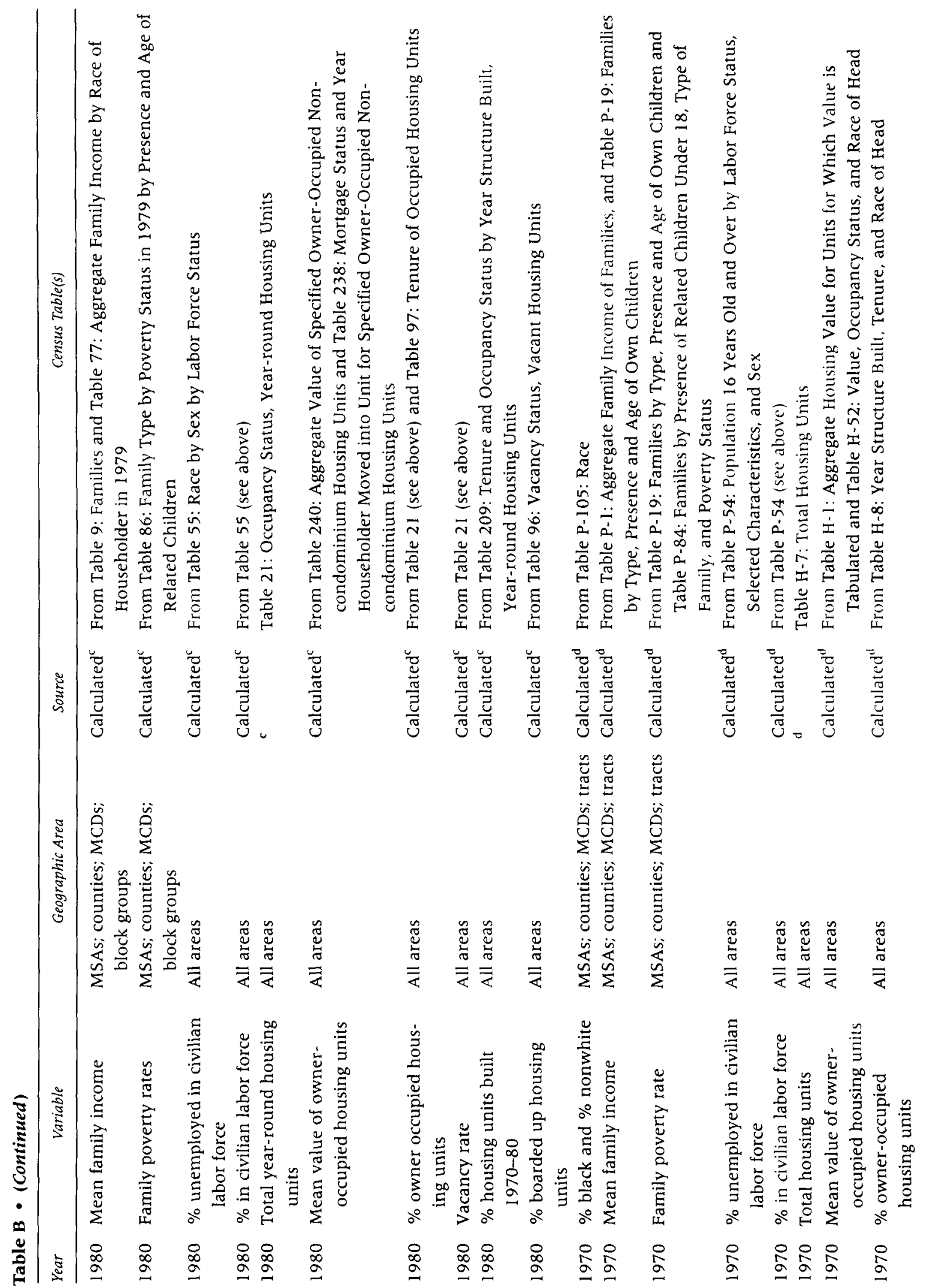




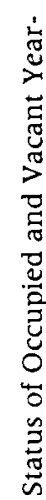

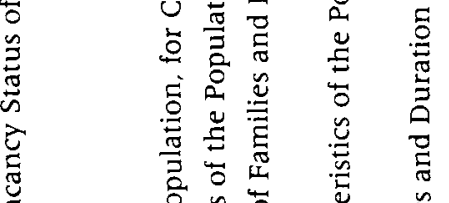

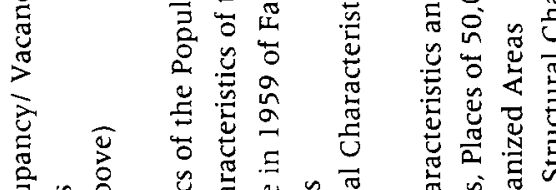

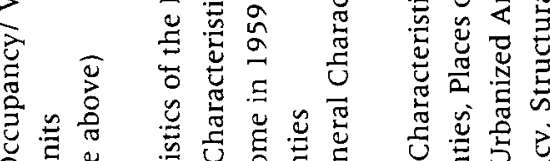

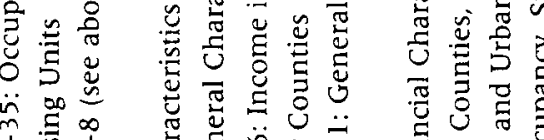

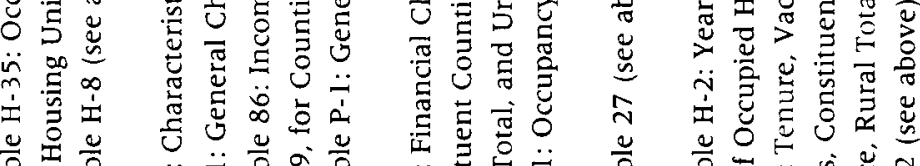

焉焉

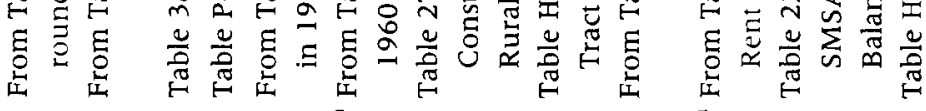

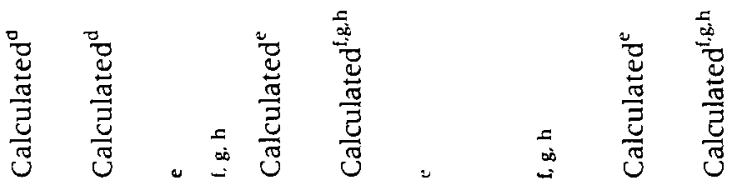
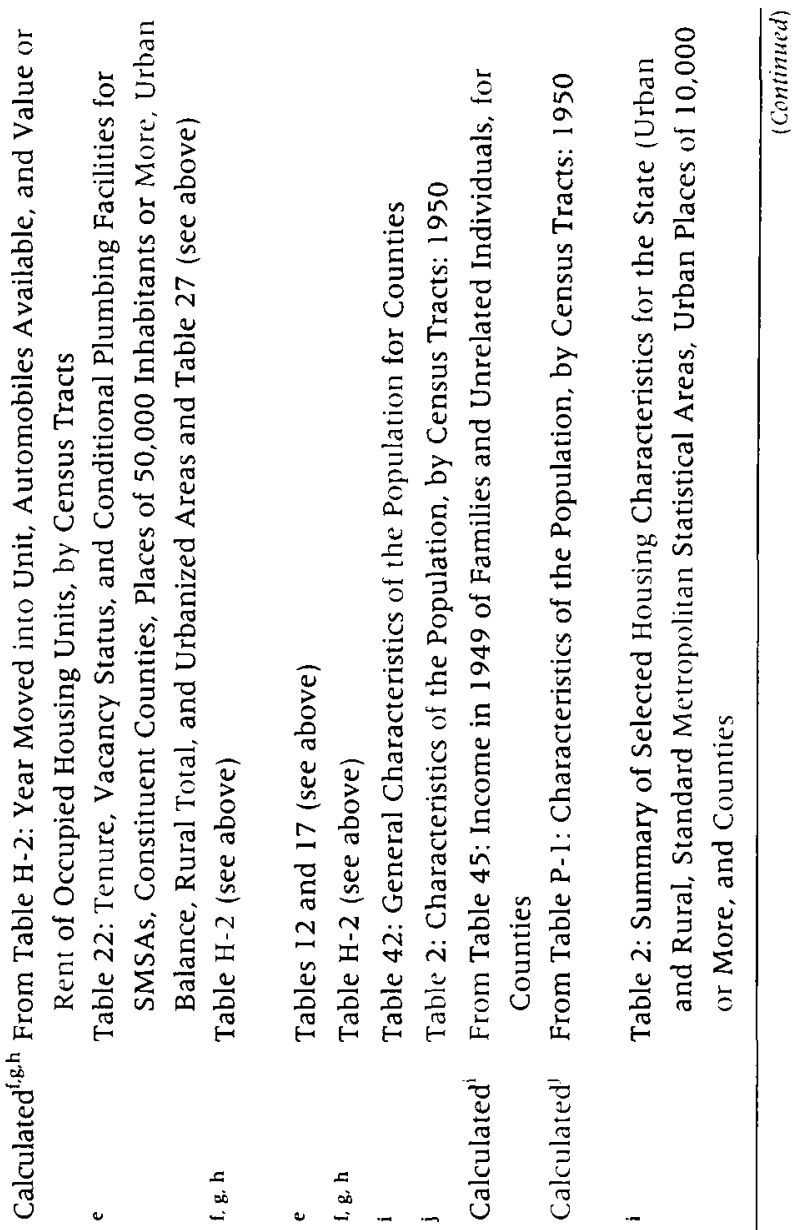

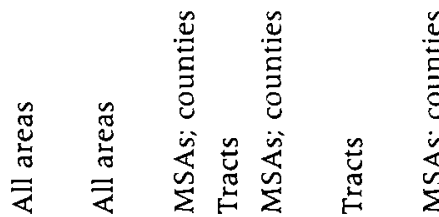

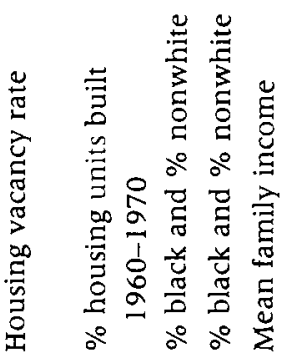

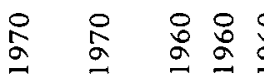

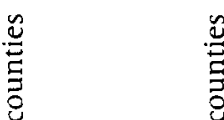

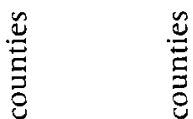

莺

s.

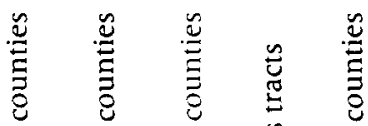

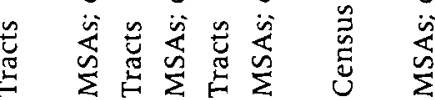

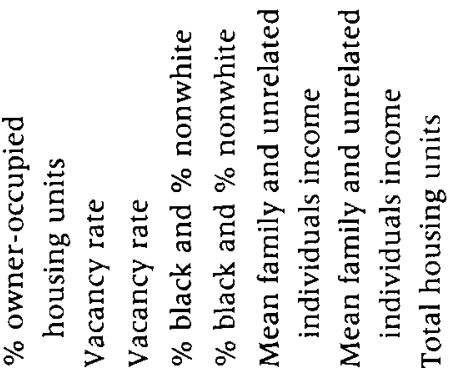

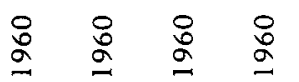

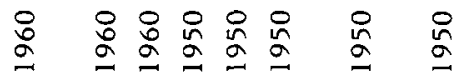




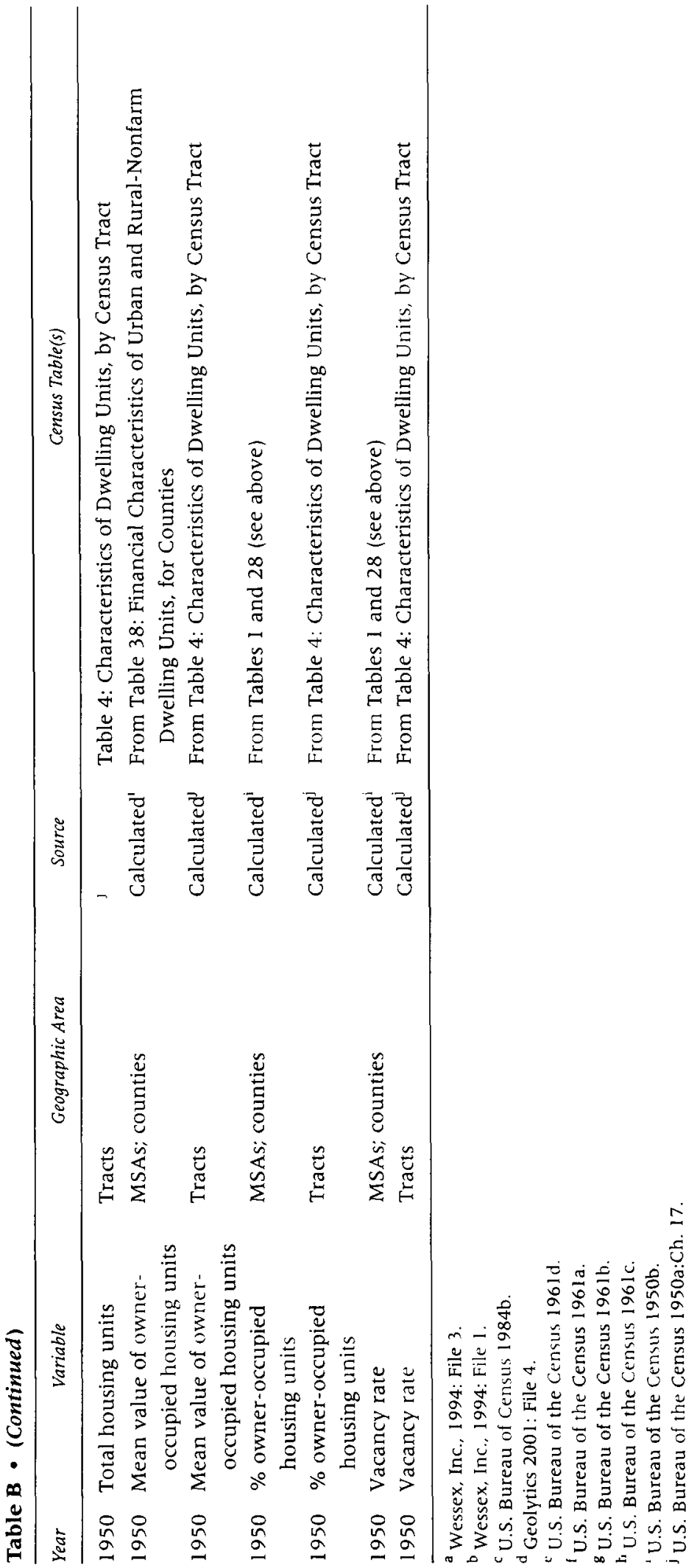




\section{References}

Anderson, Andy B., Douglas L. Anderton, and John Michael Oakes. 1994. "Environmental Equity: Evaluating TSDF Siting over the Past Two Decades." Waste Age 25(7): 83-100.

Bacow, Lawrence S. and James R. Milkey. 1982. “Overcoming Local Opposition to Hazardous Waste Facilities: The Massachusetts Approach." Harvard Environmental Law Review 6:265-305.

Baibergenova, Akerke, Rustam Kudyakov, Michael Zdeb, and David O. Carpenter. 2003. "Low Birth Weight and Residential Proximity to PCB-contaminated Waste Sites." Environmental Health Perspectives 111:1352-57.

Been, Vicki. 1994. "Locally Undesirable Land Uses in Minority Neighborhoods: Disproportionate Siting or Market Dynamics." The Yale Law Journal 103:1383-1422.

Been, Vicki and Francis Gupta. 1997. "Coming to the Nuisance or Going to the Barrios? A Longitudinal Analysis or Environmental Justice Claims." Ecology Law Quarterly 24:1-56.

Blumberg, Louis and Robert Gottlieb. 1989. War on Waste: Can America Win Its Battle with Garbage. Covelo, CA: Island Press.

Bohon, Stephanie A. and Craig R. Humphrey. 2000, "Courting LULUs: Characteristics of Suitor and Objector Communities." Rural Sociology 65:376-95.

Boone, Christopher G. and Ali Modarres. 1999. "Creating a Toxic Neighborhood in Los Angeles County: A Historical Examination of Environmental Inequality." Urban Affairs Review 35:163-87.

Brown, Michael H. 1981. Laying Waste: The Poisoning of America by Toxic Chemicals. New York: Washington Square Press.

Brown, Phil. 1995. “Race, Class, and Environmental Health: A Review and Systemization of the Literature." Environmental Research 69:15-30.

Brulle, Robert J. 2000. Agency, Democracy, and Nature: The U.S. Environmental Movement from a Critical Theory Perspective. Cambridge, MA: The MIT Press.

Bryant, Bunyan, ed. 1995. Environmental Justice: Issues, Policies, and Solutions. Washington, DC: Island Press.

Bullard, Robert D. 1983. "Solid Waste Sites and the Black Houston Community." Sociological Inquiry 53:273-88.

1990. Dumping in Dixie: Race, Class, and Environmental Quality. Boulder, CO: Westview Press.

Bullard, Robert D. and Beverly Hendrix Wright. 1987. "Blacks and the Environment." Humboldt Journal of Social Relations 14(1/2): 165-84.

Cable, Shari and Michael Benson. 1993. "Acting Locally: Environmental Injustice and the Emergence of Grassroots Environmental Organizations." Social Problems 40:464-77.

Cerrell Associates, Inc. 1984. "Political Difficulties Facing Waste-to-energy Conversion Plant Siting." Report prepared for California Waste Management Board, Los Angeles, CA.

Chakraborty, Jayajit and Marc P. Armstrong. 1997. "Exploring the Use of Buffer Analysis for the Identification of Impacted Areas in Environmental Equity Assessment." Cartography and Geographic Information Systems 24(3): I 45-57.

Cole, Luke W. and Sheila R. Foster. 2001. From the Ground Up: Environmental Racism and the Rise of the Environmental Justice Movement. New York: New York University Press.

Daly, John B. and Eric N. Vitaliano. 1987. Hazardous Waste Facility Siting: A National Survey. Albany, NY: Legislative Commission on Toxic Substances and Hazardous Wastes.

Davis, Charles E. 1993. The Politics of Hazardous Waste. Englewood Cliffs, NJ: Simon \& Schuster.

Davy, Benjamin. 1997. Essential Justice: When Legal Institutions Cannot Resolve Environmental and Land Use Disputes. New York: Springer-Verlag Wien.

Dinkins, Carol E. 1995. "Impact of the Environmental Justice Movement on American Industry and Local Government." Administrative Law Review 47:337-53.

Dunlap, Riley E. 1992. "Trends in Public Opinion toward Environmental Issues: 1965-1990." Pp. 89-116 in American Environmentalism, edited by Riley E. Dunlap and Angela G. Mertig. Washington, DC: Taylor and Francis New York Inc.

Edelstein, Michael R. 1988. Contaminated Communities: The Social and Psychological Impacts of Residential Toxic Exposure. Boulder, CO: Westview Press.

Feagin, Joe R. and Clarece B. Feagin 1986. Discrimination American Style: Institutional Racism and Sexism. 2d ed. Malabar, FL: Kriege Publishing Co.

Fletcher, Thomas H. 2003. From Love Canal to Environmental Justice: The Politics of Hazardous Waste on the Canada-U.S. Border. Peterborough, Ontario: Broadview Press.

Freudenberg, Nicholas. 1984. "Citizen Action for Environmental Health: Report on a Survey of Community Organizations." American Journal of Public Health 74:444-48. 
Freudenberg, Nicholas and Carol Steinsapir. 1991. "Not in Our Backyards: The Grassroots Environmental Movement." Society and Natural Resources 4:235-45.

Freudenberg, William R. 1997. "Contamination, Corrosion, and the Social Order: An Overview." Current Sociology 45(3): 19-39.

Furuseth, Owen J. 1989. "Community Sensitivity to a Hazardous Waste Facility." Landscape and Urban Planning 17:357-70.

Geolytics Inc. 1998. CensusCD+Maps Version 3.0. New Brunswick, NJ: GeoLytics Inc.

- 1999. StreetCD 98. New Brunswick, NJ: Geolytics Inc. 2001. CensusCD 1970. New Brunswick, NJ: GeoLytics Inc.

Gibb, Lois M. 1982. Love Canal: My Story. Albany, NY: State University of New York Press.

Glickman, Theodore S. 1994. "Measuring Environmental Equity with GIS." Renewable Resources Journal $12(3): 17-21$.

Glickman, T. S., D. Golding, and R. Hersh. 1995. “GIS-Based Environmental Equity Analysis-A Case Study of TRI Facilities in the Pittsburgh Area." Pp. 95-1 14 in Computer Supported Risk Management, edited by G. E. G. Beroggi and W. A. Wallace. Dordrecht, Netherlands: Kluwer Academic.

Gottlieb, Robert. 1993. Forcing the Spring: The Transformation of the American Environmental Movement. Washington, DC: Island Press.

Hamilton, James T. 1993. "Politics and Social Costs: Estimating the Impact of Collective Action on Hazardous Waste Facilities." RAND Journal of Economics 24(1): 10I-25.

-. 1995. "Testing for Environmental Racism: Prejudice, Profits, Political Power?" Journal of Policy Analysis and Management 14(1): 107-32.

Hamilton, James T. and W. Kip Viscusi. 1999. Calculating Risks? The Spatial and Political Dimensions of Hazardous Waste Policy. Cambridge, MA and London: The MIT Press.

Hersh, Robert. 1995. Race and Industrial Hazards: An Historical Geography of the Pittsburgh Region, 1900-1990. Discussion Paper 95-18. Washington, DC: Resources for the Future.

Hurley, Andrew. 1995. Environmental Inequities: Class, Race, and Industrial Pollution in Gary, Indiana, 19451990. Chapel Hill: University of North Carolina Press.

- 1997. "Fiasco at Wagner Electric: Environmental Justice and Urban Geography in St. Louis." Environmental History 2:460-81.

Hurwitz, Julie H. and E. Quita Sullivan. 2001. "Using Civil Rights Law to Challenge Environmental Racism: From Bean to Guardians to Chester to Sandoval." The Journal of Law in Society 2:5-70.

Jargowsky, Paul A. 1997. Poverty and Place: Ghettos, Barrios, and the American City. New York: Russell Sage Foundation.

Kanagy, Conrad L., Craig R. Humphrey, and Glenn Firebaugh. 1994. "Surging Environmentalism: Changing Public Opinion of Changing Publics?" Social Science Quarterly 75:804-19.

Kasperson, Roger E. 1986. "Hazardous Waste Facility Siting: Community, Firm, and Governmental Perspectives." Pp. 118-44 in Hazards: Technology and Fairness. Washington, DC: National Academy Press.

Krieg, Eric J. 1995. "A Socio-Historical Interpretation of Toxic Waste Sites: The Case of Great Boston." The American Journal of Economics and Sociology 54(1): 1-14.

Kraft, Michael E. and Ruth Kraut. 1988. "Citizen Participation and Hazardous Waste Policy Implementation." Pp. 63-80 in Dimensions of Hazardous Waste Policy, edited by Charles E. Davis and James P. Lester. New York: Greenwood Press.

Lake, Robert W. 1996. "Volunteers, NIMBY, and Environmental Justice: Dilemmas of Democratic Practice." Antipode 28:160-74.

Levine, Adeline. 1982. Love Canal: Science, Politics, and People. Lexington, MA: Lexington Books.

Lindell, M. and T. Earle. 1983. "How Close Is Close Enough: Public Perception of the Risks of Industrial Facilities." Risk Analysis 3:245-53.

Massey, Douglas S. and Nancy A. Denton. 1993. American Apartheid: Segregation and the Making of the Underclass. Cambridge, MA: Harvard University Press.

Mazmanian, Daniel A. and David Morell. 1994. "The 'NIMBY' Syndrome: Facility Siting and the Failure of Democratic Discourse." Pp. 233-50 in Environmental Policy in the 1990s: Toward a New Agenda, 2d ed., edited by Norman J. Vig and Michael E. Kraft. Washington, DC: Congressional Quarterly Press.

McAdam, Doug. 1982. Political Process and the Development of Black Insurgency, 1930-1970. Chicago: University of Chicago Press.

Mitchell, Jerry T., Deborah S. K. Thomas, and Susan L. Cutter. 1999. "Dumping in Dixie Revisited: The Evolution of Environmental Injustices in South Carolina." Social Science Quarterly 80:229-43.

Mohai, Paul and Bunyan Bryant. 1992. "Environmental Racism: Reviewing the Evidence." Pp. 163-76 in Race and the Incidence of Environmental Hazards: A Time for Discourse, edited by Bunyan Bryant and Paul Mohai. Boulder, CO: Westview Press. 
Mohai, Paul and Robin Saha. 2003. "Reassessing Race and Class Disparities in Environmental Justice Research Using Distance-based Methods." Paper presented at the Annual Meeting of the American Sociological Association, Atlanta, GA, August 16-19.

Montrie, Chad. 2005. "From Dairy Farms to Housing Tracts: Environment and Race in the Making of a Memphis Suburb." Journal of Urban History 31 (2): 21 9-40.

Morell, David and Christopher Magorian. 1982. Siting Hazardous Waste Facilities: Local Opposition and the Myth of Preemption. Cambridge, MA: Ballinger.

Morrison, Denton. 1986. "How and Why Environmental Consciousness Has Trickled Down." Pp. 187220 in Distributional Conflicts in Environmental and Resource Policy, edited by Allan Schnaiberg, Nicholas Watts, and Klaus Zimmerman. Aldershot, UK: Gower Publishing Company Limited.

Moss, Kary L. 2001. "Environmental Justice at the Crossroads." The Journal of Law in Society 2:71-108.

National Governors' Association (NGA). 1981. "Siting Hazardous Waste Facilities." The Environmental Professional 3:133-42.

Nelson, Arthur C., Michelle Genereux, and John Genereux. 1992. "Price Effects of Landfills on House Values." Land Economics 68:359-65.

Oakes, John Michael, Douglas L. Anderton, and Andy B. Anderson. 1996. "A Longitudinal Analysis of Environmental Equity in Communities with Hazardous Waste Facilities." Social Science Research 23:125-48.

O'Hare, Michael, Lawrence Bacow, and Debra Sanderson. 1983. Facility Siting and Public Opposition. New York: Van Nostrand Reinhold.

Oregon Department of Forestry. 2003. "XTools Description." Oregon Department of Forestry. Salem, OR: Oregon Department of Forestry. Retrieved May 17, 2005 (http://www.odf.state.or.us/divisions/ management/state_forests/GIS/Documents/xtools.htm).

Pastor, Manuel, Jr., Jim Sadd, and John Hipp. 2001. "Which Came First? Toxic Facilities, Minority Movein, and Environmental Justice." Journal of Urban Affairs 23:1-21.

Pellow, David N. 2000. "Environmental Inequality Formation: Toward a Theory of Environmental Injustice." American Behavioral Scientist 43:581-601.

- 2002. Garbage Wars: The Struggle for Environmental Justice in Chicago. Cambridge, MA: MIT Press.

Portney, Kent E. 1991a. Siting Hazardous Waste Treatment Facilities: The NIMBY Syndrome. New York: Auburn House.

- 199 1b. "Public Environmental Policy Decision Making: Citizen Roles." Pp. 195-215 in Environmental Decision Making: A Multidisciplinary Perspective, edited by Richard A. Chechila and Susan Carlisle. New York: Van Nostrand Reinhold.

Pulido, Laura. 1996. "A Critical Review of the Methodology of Environmental Racism Research." Antipode 28:142-59.

- 2000. "Rethinking Environmental Racism: White Privilege and Urban Development in Southern California." Annals of the Association of American Geographers 90:12-40.

Pulido, Laura, Steve Sidawi, and Robert O. Vos. 1996. “An Archaeology of Environmental Racism in Los Angeles." Urban Geography 17:419-39.

Quarantelli, E. L. 1989. "Characteristics of Citizen Groups which Emerge with Respect to Hazardous Waste Sites." Pp. 177-95 in Psychosocial Effects of Hazardous and Toxic Waste Disposal on Communities, edited by Dennis L. Peck. Springfield, IL: Charles C. Thomas.

Rabe, Barry G. 1994. Beyond NIMBY: Hazardous Waste Siting in Canada and the United States. Washington, DC: The Brookings Institute.

Reich, Michael R. 1991. Toxic Politics: Responding to Chemical Disasters. Ithaca, NY: Cornell University Press.

Ringquist, Evan. 2005. "Assessing Evidence of Environmental Inequalities: A Meta-analysis." Journal of Policy Analysis and Management 24:223-48.

Saha, Robin and Paul Mohai. 1997. "Explaining Racial and Socioeconomic Disparities in the Location of Locally Unwanted Land Uses: A Conceptual Framework." Presented at the Annual Meeting of the Rural Sociological Society, Toronto, Canada, August 15-17.

Sandman, Peter M. 1985. "Getting to Maybe: Some Communications Aspects of Siting Hazardous Waste Facilities." Seton Hall Legislative Journal 9:437-65.

Schlosberg, David. 1999. Environmental Justice and the New Pluralism: The Challenge of Difference for Environmentalism. New York: Oxford University Press.

Sheppard, Eric, Helga Leitner, Robert B. McMaster, and Hongguo Tian. 1999. "GIS-based Measures of Environmental Equity: Exploring Their Sensitivity and Significance." Journal of Exposure Analysis and Environmental Epidemiology 9:18-28.

Sliver, Steven. 1993. Hazardous Waste Program Officer, Michigan Department of Natural Resources, Phone Interview, n.d. 
Stretesky, Paul and Michael J. Hogan. 1998. "Environmental Justice: An Analysis of Superfund Sites in Florida." Social Problems 45:268-87.

Sugrue, Thomas J. 1996. The Origins of the Urban Crisis: Race and Inequality in Postwar Detroit. Princeton, NJ: Princeton University Press.

Szasz, Andrew. 1994. EcoPopulism: Toxic Waste and the Movement for Environmental Justice. 2d ed. Minneapolis: University of Minnesota Press.

Szasz, Andrew and Michael Meuser. 2000. "Unintended, Inexorable: The Production of Environmental Inequalities in Santa Clara County, California." American Behavioral Scientist 43:602-32.

Tarrow, Sidney 1996. "States and Opportunities: The Political Structuring of Social Movements." Pp. $41-$ 60 in Comparative Perspectives on Social Movements: Political Opportunities, Mobilizing Structures, and Cultural Framing, edited by Doug McAdam, John D. McCarthy, and Mayer N. Zald. Cambridge: Cambridge University Press.

Taylor, Dorceta E. 1993. "Environmentalism and the Politics of Inclusion." Pp. 53-6I in Confronting Environmental Racism: Voices from the Grassroots, edited by Robert D. Bullard. Boston: South End Press.

- 1997. "American Environmentalism: The Role of Race, Class, and Gender in Shaping Activism 1820-1995." Race, Gender $\theta$ Class 5:16-62.

- 1998. "Mobilizing for Environmental Justice in Communities of Color: An Emerging Profile of People of Color Environmental Groups." Pp. 32-67 in Ecosystem Management: Adaptive Strategies for Natural Resource Organizations in the 21st Century, edited by Jennifer Alley, William R. Burch, Beth Canover, and Donald Field. Philadelphia, PA: Taylor \& Francis.

- 2000. "The Rise of the Environmental Justice Paradigm: Injustice Framing and the Social Construction of Environmental Discourse." American Behavioral Scientist 43:508-80.

U.S. Bureau of the Census. 1950a. Census of Population, Census Tract Statistics, Detroit, Michigan and Adjacent Area. Vol. III. Washington, DC: U.S. Government Printing Office.

. 1950b. Census of Population. Vol. II, Part 22, "Characteristics of the Population." Washington, DC: U.S. Government Printing Office.

-1961a. Census of Population and Housing, 1960, Census Tracts, Detroit, Michigan, Standard Metropolitan Statistical Area. PHC(1)-40. Washington, DC: U.S. Government Printing Office.

- 1961 b. Census of Population and Housing, 1960, Census Tracts, Grand Rapids, Michigan, Standard Metropolitan Statistical Area. PHC(1)-54, Washington, DC: U.S. Government Printing Office.

1961c. Census of Population and Housing, 1960. Census Tracts, Muskegon-Muskegon Heights, Michigan. Standard Metropolitan Statistical Area. PHC(1)-98. Washington, DC: U.S. Government Printing Office.

-1961d. Census of Population, 1960. Vol. 1, Part 24, "Characteristics of the Population, Michigan." Washington, DC: U.S. Government Printing Office.

1970. Census Users Guide. Washington, DC: Government Printing Office.

1984a [1982]. Census of Population and Housing, 1980 (United States): Summary Tape File 3A. Washington, DC: United States Department of Commerce, Bureau of the Census.

- 1984b [1982]. Technical Documentation, Census of Population and Housing, 1980 (United States): Summary Tape File 3A. Washington, DC: United States Department of Commerce, Bureau of the Census [producer]. Ann Arbor, MI: Inter-university Consortium for Political and Social Research [distributor].

U.S. EPA Office of Solid Waste. 1990. RCRA Orientation Manual: 1990 Edition. EPA 530-SW-90-036. Washington, DC: U.S. Government Printing Office.

U.S. EPA Office of Water and Waste Management. 1979. Siting of Hazardous Waste Management Facilities and Public Opposition. EPA SW 809. Washington, DC: Government Printing Office.

U.S. General Accounting Office (U.S. GAO). 1983. Siting of Hazardous Waste Landfills and Their Correlation with Racial and Economic Status of Surrounding Communities. RCED-83-168. Washington, DC: U.S. General Accounting Office.

- 1995. Hazardous and Nonhazardous Waste: Demographics of People Living near Waste Facilities. RCED95-84. Washington, DC: U.S. General Accounting Office.

Vrijheid M., H. Dolk, B. Armstrong, G. Boschi, A. Busby, T. Jorgensen, and P. Pointer. 2002. “Hazard Potential Ranking of Hazardous Waste Landfill Sites and Risk of Congenital Anomalies." Journal of Occupational and Environmental Medicine 59:768-76.

Wessex Inc., 1994 [1992]. 1990 Census of Population and Housing. Summary Tape Files 1A and 3A. Washington, DC: U. S. Bureau of the Census [producer]. Winnetka, IL: Author [distributor].

Wessex Inc. 1995. 1990 TIGER Files [CD-ROM]. Winnetka, IL: Wessex Inc.

Wilson, Carter A. 1992. "Restructuring and the Growth of Concentrated Poverty in Detroit." Urban Affairs Quarterly 28:187-205.

Wilson, William J. 1987. The Truly Disadvantaged. Chicago, IL: University of Chicago Press. 


\section{THANKS TO REVIEWERS}

The success of Social Problems depends on a community of contributors. We are grateful for the advice and support of the Board of Advisory Editors and the Editorial and Publications Committee of the Society for the Study of Social Problems. We owe a special debt of gratitude to our many colleagues who serve as referees in the peer review process. The following people reviewed at least one manuscript for us in the past year. Thank you. It's your work that distinguishes Social Problems.

James A. Holstein, Editor Stephen L. Franzoi, Associate Editor Carol A. Archbold, Deputy Editor

\author{
Nancy Abelmann \\ Laura S. Abrams \\ Joan Acker \\ Barry D. Adam \\ Robert Adelman \\ Peter Adler \\ Victor Agadjanian \\ Karin Aguilar-San Juan \\ Michael B. Aguilera \\ James W. Ainsworth \\ Ronald L. Akers \\ Malin Akerstrom \\ Richard Alba \\ Celesta A. Albonetti \\ Jeffrey Alexander \\ Katherine R. Allen \\ Louisa Allen \\ Paul Almeida \\ Gaston Alonso \\ David L. Altheide \\ Duane F. Alwin \\ Nancy Ammerman \\ Margaret L. Andersen \\ Elijah Anderson \\ Kristin L. Anderson \\ Leon Anderson \\ Paul Anderson \\ Lois Andre-Bechely \\ Vernon Andrews \\ Kenneth T. Andrews \\ Sylvia J. Ansay \\ Renee R. Anspach \\ Jean Anyon \\ Ralph Armbruster-Sandoval \\ Ilkka Arminen \\ Elizabeth A. Armstrong \\ Marilyn Aronoff
}

\author{
Bruce A. Arrigo \\ Michael Ash \\ William Avison \\ Jun Ayukawa \\ Jerald Bachman \\ Christopher Bader \\ Stanley R. Bailey \\ William C. Bailey \\ Derek Ball \\ Deborah Balser \\ Lee Ann Banaszak \\ Gregg Barak \\ Steven E. Barkan \\ Melissa Barlow \\ Emily Barman \\ Sharon Barnartt \\ Sandra Barnes \\ Michael L. Barnett \\ Donald Barrett \\ Bernadette Barton
}

Eric Baumer

Frank R. Baumgartner

Dawn Baunach

Frank Bean

Irenee Beattic

E. M. Beck

Natalie Becker

Katherine Beckett

Jason Beckfield

Sharon Beder

Leonard Beeghley

Susan E. Bell

Brent Benda

Chris Benner

Pam Bennett

John M. Benson

Michael Benson
Rodney Benson

Timothy J. Berard

Mitchell Berbrier

Raquel Bergen

Ronald Berger

Richard Berk

Nancy Berns

Mary Bernstein

Amy Best

Joel Best

Bruce Biddle

Denise D. Bielby

$\mathrm{M}$. J. Bienvenu

Robert Biggert

David Bills

Donna Bishop

Edward J. Blakely

Jon Bloch

Jason Boardman

Natalie Boero

Cynthia J. Bogard

Stephanie Bohon

Edna Bonacich

Eduardo Bonilla-Silva

Karen M. Booth

Eileen C. Boris

Charles L. Bosk

Mary Bosworth

Shaun Bowler

Elizabeth H. Boyle

Mindy Bradley

John Braithwaite

Wayne Brekhus

Mark D. Brewer

Laura Briggs

Kendal Broad

Beckett Broh

Social Problems, Vol. 52, Issue 4, pp. 649-655, ISSN 0037-7791, electronic ISSN 1533-8533.

(C) 2005 by Society for the Study of Social Problems, Inc. All rights reserved. Please direct all requests for permission to photocopy or reproduce article content through the University of California Press's Rights and Permissions website, at http://www. ucpress.edu/journals/rights.htm. 
Lisa Marie Broidy

David G. Bromley

David Brotherton

B. Bradford Brown

Cliff Brown

Phil Brown

Susan K. Brown

John Brueggemann

Robert J. Brulle

Bethany Bryson

Dave Buckholdt

Michelle Budig

Steven M. Buechler

Stacy L. Burns

Val Burris

Robert Bursik

Paul Burstein

Lawrence Busch

Melanie Bush

Shawn Bushway

Sheri-Ann Butterfield

Patrice Buzzanell

Michelle Byng

Sherry Cable

Kitty Calavita

Peter L. Callero

Karen E. Campbell

Marie L. Campbell

Beth Schaefer Caniglia

Randy Capps

Diana B. Carlin

Cheryl Carpenter

C. Lynn Carr

Patrick Carroll

William K. Carroll

Russell A. Castro

Ralph Catalano

Nancy K. Cauthen

Gray Cavender

James Cavendish

Mitchell Chamlin

Dean J. Champion

Lynn Chancer

Susan E. Chase

Leo Chavez

Steven Chermak

Mark A. Chesler

Roland Chilton

Joyce Chinen

Ted G. Chiricos

Lars Christiansen

Marisol Clark-Ibanez

Dan Clawson

Mary Ann Clawson

Steven E. Clayman

Elisabeth S. Clemens

Jay Coakley
John K. Cochran

William Cockerham

Amanda Coffey

Mark Cohan

Philip N. Cohen

Theodore F. Cohen

Glenna S. Colclough

Frances Scott Coles

Roberta Coles

Sharon Collins

Scott Coltrane

Mark Colvin

Dennis Condron

Peter Conrad

Gary A. Cook

Jared Cootz

Patrick Corrigan

Chris Coryn

Carrie Yang Costello

David A. Cotter

Stephen R. Couch

Susan Coutin

Jeanette Covington

Jonathan Crane

Cynthia Cranford

John P. Crank

Sara Crawley

Edward Crenshaw

Jennifer Croissant

Robert Crosnoe

Nick Crossley

Katherine Culotta

David Cunningham

Sara R. Curran

G. David Curry

Timothy Curry

William F. Danaher

Arlene Daniels

Joseph E. Davis

Randy Day

Heather D'Cruz

Michael DeCesare

Scott Decker

Mathieu Deflem

Regina Deil-Amen

Debra DeLaet

Kevin Delaney

Hector L. Delgado

Matt DeLisi

Kirsten Dellinger

Miriam DeLone

Stephanie Deluca

Gerald de Montigny

Stephen Demuth

Melinda Denton

Joseph de Rivera

Marjorie L. DeVault
Lisa Diamond

Timothy Diamond

M. Thaxter Dickey

Thomas Dietz

Ronit Dinovitzer

Marc Dixon

Travis Dixon

Ashley Woody Doane, Jr.

G. William Domhoff

Silvia Dominguez

Brian Donovan

Keith Doubt

Olivia Douglass

Timothy Dowd

Dennis J. Downey

Liam Downey

Aaron Doyle

Paul Drew

David Duffee

Chris Dunbar

Michele D. Dunbar

Rachel Dunifon

Jennifer Leigh Dunn

Shari L. Dworkin

Rachel Dwyer

Jennifer Earl

Jacquelynne S. Eccles

Beth A. Eck

Penny Edgell

Charles Edgley

Bob Edwards

Peter Eglin

Howard Ehrlich

Jennifer Eichstedt

Rachel L. Einwohner

Tamela M. Eitle

James R. Elliott

Christopher G. Ellison

Yuval Elmelech

Jean Elson

Michael Emerson

Michael O. Emerson

Robert M. Emerson

Paula England

Cynthia Fuchs Epstein

Steven Epstein

Edna Erez

Rebecca Erickson

Sarah Eschholz

Yen Le Espiritu

Sarah Beth Estes

Patricia Ewick

Sara Exposito

Gil Eyal

Chris Faircloth

Catherine Faver

Cynthia Feliciano 
James Fendrich Marilyn Fernandez Roberto Fernandez Kathleen J. Ferraro Tina Fetner Danielle Fettes Joel S. Fetzer Jessica Fields Betsy Fife Deborah M. Figart Anne E. Figert Gary Alan Fine Laura Fingerson Susan Finley Benedikt Fischer Allen P. Fisher Dana Fisher Scott T. Fitzgerald Robyn Fivush Michael Flaherty Catherine Fobes Amy C. Foerster Lara Foley Michael W. Foley Mary Margaret Fonow Jorge Fontdevila Cecilia Ford Tyrone A. Forman Greer Litton Fox Kathryn J. Fox David John Frank Josh Freely William R. Freudenberg James A. Frey R. Scott Frey Scott Frickel Samantha Friedman David O. Friedrichs Lisa Frohmann Lynn Fujiwara Hiroshi Fukurai Robert Futrell Patricia Gagne George Gaither Joseph Galaskiewicz Charles A. Gallagher John Galliher Gail Gamache Adam Gamoran Joshua P. Gamson William A. Gamson Marshall Ganz Angela Garcia Carol B. Gardner Gilbert Geis Andrew Gelman Linda George
J. William Gibson Elizabeth Gill Jennifer Glanville Steven J. Gold Thomas Gold Walter Goldfrank Pat Goldsmith Steven Gorelick Bridget $\mathrm{K}$. Gorman Kimberly A. Goyette Franklin Goza Kamini Grahame Peter R. Grahame Harold Grasmick Ryken Grattet David Grazian Donald Green Donald E. Green David F. Greenberg Larry J. Griffin Alison I. Griffith Laura Grindstaff Eric Grodsky William Gronfein Kathleen Grove Aline Gubrium Jaber F. Gubrium John Guidry Valerie J. Gunter David Gutierrez Jacqueline Hagan John L. Hagan John M. Hagedorn Donald P. Haider-Markel Herbert H. Haines

Drew Halfmann

Tim Halkowski

Peter M. Hall

Jennifer Hamer Lynne Haney John Hannigan Christine Harrington Scott Harris John Hartigan William T. Hartman Douglas Hartmann Richard D. Harvey Yeheskel Hasenfeld Donald W. Hastings Laurie Russell Hatch Stephani Hatch Katherine Hausbeck Robert Hawkins Christian Heath Karen Heimer Julia Henly John C. Henretta
P. J. Henry

Kevin D. Henson

Steven K. Herbert

John Heritage

Nancy Herman-Kinney

Joan Hermsen

Barbara Heron

Scott Hershberger

Stephen Hester

John D. Hewitt

Alexander Hicks

Richard Hilbert

Azita Hirsa

Eric Hirsch

Lindsay Hirschfeld

Pensri Ho

Dennis Hogan

Michael Hogan

Jarita Holbrook

Jocelyn Hollander

David Holleran

Kristy Holtfreter

Pierette Hondagneu-Sotelo

Jane C. Hood

M. V. (Trey) Hood III

Allan V. Horwitz

Ruth Horowitz

Stephanie Howling

William Hoynes

Kenneth Hudson

Matt Huffman

Darnell $M$. Hunt

Scott Hunt

Peter R. Ibarra

John Iceland

Nikitah Okembe-Imani

David Inglis

James $M$. Inverarity

Janice Irvine

Leslie Irvine

Larry Isaac

Jonathan Isler

Mary Jackman

Nancy Jackson

David Jacobs

Katarina Jacobsson

Craig Janes

Susan Jekielek

Valerie Jenness

Paul D. Jesilow

Bruce Johnson

Byron Johnson

David R. Johnson

Delia Johnson

Janet Johnson

Kirk A. Johnson

Monica Kirkpatrick Johnson 
Victoria Johnson

Lynn C. Jones

Nikki Jones

Richard Jones

Elizabeth Joniak

Andrew Jorgenson

Kara Joyner

Alice Julier

Nancy C. Jurik

Cheryl Kaiser

Seth Kalichman

Will Kalkhoff

Nina Kammerer

Melinda Kane

Stephanie Kane

Elaine Bell Kaplan

Thomas Kaplan

Marina Karides

Jack Katz

Michael B. Katz

Susan Keefe

Veru Keesari

Christa Kelleher

Michael D. Kennedy

Kevin Keogan

Kent Kerley

Edward L. Kick

Hyun Sook Kim

Howard A. Kimeldorf

William R. King

Ann Marie Kinnell

David A. Kinney

Maren Klawiter

Robert Kleidman

Lloyd Klein

Eric M. Klinenberg

David Klinger

James R. Kluegel

Joshua Klugman

Julie A. Kmec

Christopher J. Kollmeyer

Lisa Konczal-Martinez

Amanda Konradi

Kathleen Korgen

Joe Kotarba

Betsy Wright Kreisel

John Krinsky

Lauren J. Krivo

Naomi Krogman

Maria Krysan

Tim Kubal

Charis E. Kubrin

Kon Kuiper

Aaron Kupchik

Prema Kurien

Margarethe Kusenbach

Dae Hoon Kwak
Ken Kyle

Karyn Lacy

Gordon Lafer

Gary LaFree

Michele Lamont

Pei-Chia Lan

Kenneth C. Land

Jodi Lane

Lauren Langman

Mark Lanier

Wendy Larcombe

Annette Lareau

Anne Larme

John H. Laub

Mickey Lauria

Thomas LaVeist

Danielle Lavin-Loucks

Regina Lawrence

Samuel Lawrence

Allen J. Leblanc

Matthew R. Lee

Matthew T. Lee

Margaret E. Leigy

Helen-Maria Lekas

Ronit Lentin

Gene Lerner

Kari Lerum

Nancy Lesko

Joel Levine

Judith A. Levine

Ellen Lewin

Charles W. Lidz

John Lie

Annulla Linders

Pauline Lipman

Kathryn Lively

Clarence Y. H. Lo

Colin Loftin

John R. Logan

Douglas Longshore

Len Lopoo

Donileen R. Loseke

Linda Loury

Setha Low

Kathleen Lowney

Timothy Luke

Paul Luken

Jenifer Hamil Luker

Doman Lum

Howard Lune

Bruce Luske

Loren Lutzenhiser

Stephen Lyng

Eleanor Lyon

Douglas H. MacBeth

Danielle MacCartney

Cameron Lynne Macdonald
Alair Maclean

Ross MacMillan

Sarah J. Mahler

David Maines

Jennifer Malat

Lawrence Mamiya

Ann Manicom

John Manzo

Eric Margolis

Gerald Markle

Fred E. Markowitz

Courtney Marlaire

Karin Martin

Patricia Yancey Martin

Theresa Martinez

Ryan Brevin Martz

Amir Marvasti

Gerald Marwell

Nicole Marwell

Douglas S. Massey

Gregory Matoesian

Ross Matsueda

Nancy Matthews

Michael O. Maume

Donna Maurer

Armand Mauss

Maralee Mayberry

Douglas W. Maynard

Patricia L. McCall

Lisa McCartan

Bill McCarthy

John D. McCarthy

Liza McCoy

Aaron McCright

Monica McDermott

Elizabeth McEneaney

Kieran McEvoy

DeeAnn McGaughey

Eileen McGurty

Nita Mary McKinley

Karyn D. McKinney

Mitchell S. McKinney

Jane D. McLeod

John G. McNutt

Beverly McPhail

Clark McPhail

Rory McVeigh

Bud Mehan

Wayne Martin Mellinger

James Messerschmidt

Michael Messner

Mary Metz

David S. Meyer

Ilan Meyer

Raymond J. Michalowski

Roslyn Arlin Mickelson

Eric Mielants 
Terance Miethe

Ruth Milkman

Ellie Miller

Gale Miller

JoAnn Miller

Jody Miller

Dragan Milovanovic

Debra Minkoff

Beth Mintz

Joya Misra

Diditi Mitra

Mark Mizruchi

Suzanne W. Model

Angela Moe

Phyllis Moen

Paul Mohai

Stephanie Moller

John Monahan

Daniel Monti

James Moody

Christopher Mooney

Patrick Mooney

Gwen Moore

Helen A. Moore

Valerie Ann Moore

Merry Morash

Laurie Morgan

Patricia Morgan

Phoebe Morgan

Stephen Morgan

William R. Morgan

Edward Morris

Jeylan T. Mortimer

Clayton Mosher

Adele Mueller

Chandra L. Muller

Charles Muntaner

Daniel J. Myers

Kristen Myers

Eric Mykhalvoskiy

Nancy Naples

Jeffrey Nash

Belinda Needham

Margaret K. Nelson

Sharon Erickson Nepstad

Kevin L. Neuhouser

Christopher Newfield

Franklin $\mathrm{Ng}$

David Nice

Lawrence T. Nichols

Christina Nippert-Eng

Steven Nock

Samuel Noh

J. Michael Oakes

Patricia O'Brien

Robert O'Brien

Sean O'Brien
Jeffrey Olick

Stacey Oliker

Jim Orcutt

John Orr

Anthony Orum

David Ost

Suzanne Ouelette

Barbara Owen

Erica Owens

Tim Owens

Gul Ozyegin

Irene Padavic

Jose Padin

Devah I. Pager

Leslie Paik

Fred Pampel

Henry Parada

Mary Pardo

Lisa Sun-Hee Park

Karen Parker

Rhacel S. Parrenas

Debora A. Paterniti

Raymond Paternoster

Dorothy A. Pawluch

Pamela Paxton

Jamie Peck

Peter Pecora

Nicholas Pedriana

William V. Pelfrey

David N. Pellow

David Penn

Joel Perlmann

Barbara Perry

Bernice Pescosolido

Michael Petrunik

Becky Pettit

Mark Peyrot

Steven Pfaff

Stephen J. Pfohl

Julie A. Phillips

Jane Piliavin

Danielle Pillet-Shore

Alex R. Piquero

Mark Pogrebin

Melvin Pollner

Anita Pomerantz

Christy Ponticelli

Eric Poole

Susan J. Popkin

Janet Poppendieck

Alejandro Portes

Winifred Poster

Deborah A. Potter

Jonathan Potter

Brian Powell

Thomas Power

Jeanne Powers
Travis C. Pratt

Lois Presser

Diane-Michel Prindeville

Marvin Prosono

Karen D. Pyke

James Quane

Lincoln Quillian

Beth A. Quinn

Michael Radelet

Adam Rafalovich

Ann Warfield Rawls

Geoff Raymond

Jo Reger

Bob Regoli

Michael Reich

Craig Reinarman

Michael Reisch

Michael D. Reisig

Claire M. Renzetti

Barbara Reskin

Suzanne Retzinger

John Reynolds

John Steadman Rice

Craig Rimmerman

Elianne Riska

Christian Ritter

Maude Rittman

Lorna Rivera

Cynthia Robbins

J. Timmons Roberts

Belinda Robnett

Pamela Roby

E. Burke Rochford

Nester Rodriguez

Paula C. Rodriguez

Emery Roe

Andrew Rojecki

Mary Romero

Vincent Roscigno

James E. Rosenbaum

Dana Rosenfeld

Richard Rosenfeld

Sarah Rosenfield

Marilyn Rosenthal

Mark S. Rosentraub

Robert J. S. Ross

Stephen L. Ross

Andrew L. Roth

Louise Roth

Esther Rothblum

Kevin Roy

Beth Rubin

Donald B. Rubin

Bob Rubinstein

Steven Rytina

Robin Saha

Leslie Sanborn 
Stephen K. Sanderson

Salvatore Saporito

Theodore M. Sasson

Joachim Savelsberg

Rik Scarce

Melissa Schaefer

Teresa L. Scheid

Scott Schieman

Traci Schlesinger

Joseph W. Schneider

Jason Schnittker

Stuart Schoenfeld

Juliet Schor

Ronnee Schreiber

Douglas P. Schrock

Michael Schudson

Michael Schwalbe

Martin D. Schwartz

Ellen Scott

Irene Serna

Linda L. Shaw

Jon Shefner

Darren E. Sherkat

Lawrence Sherman

Rachel Sherman

Shu-mei Shih

Edward S. Shihadeh

Anne B. Shlay

Phil Shon

Neal Shover

Thomas E. Shriver

David Shulman

Diane Sicotte

Kristine Siefert

David Sikkink

Linda Silber

Eric Silver

Robert Mark Silverman

Merril Silverstein

Robin Simon

Wendy S. Simonds

Sally Simpson

Simon Singer

Sheryl Skaggs

Mario Small

Brad Smith

Charles W. Smith

Christian Smith

Dorothy Smith

M. Dwayne Smith

Pam Smith

Rob Smith

Sandra S. Smith

Vicki Smith

Linda Smolak

David A. Snow

Mary Gail Snyder
Jeffrey Sobal

Teresa Sobieszczyk

Brenda Solomon

David Sommerfeld

Joe Soss

Sarah A. Soule

Scott J. South

Caleb Southworth

Joan Z. Spade

Malcolm Spector

Susan Speer

J. William Spencer

Cassia Spohn

Gregory Squires

Craig St. John

Suzanne Staggenborg

Annegret Staiger

Peter N. Stearns

Sara Steen

Darrell Steffensmeier

Arlene Stein

Marc W. Steinberg

Suzanne Steinmetz

Judy Stepan-Norris

Quincy Stewart

Randy Stoecker

Mindy Stombler

Paul Stretesky

Brian Stults

Teresa A. Sullivan

William J. Swart

Teresa Swartz

Brian Sweeney

Ian Taplin

Sidney G. Tarrow

Diane Taub

Judith Taylor

Verta Taylor

Brent E. Teasdale

Richard Tewksbury

James Thomas

Kevin Thompson

Susan Beth Tiano

Kathleen J. Tierney

Lisa Tillmann-Healy

Chris Tilly

Jeffrey Timberlake

George Tita

Charles R. Tittle

Stewart E. Tolnay

Michael H. Tonry

Lisa Torres

Karen Tracy

Sarah Tracy

Sharon Traweek

Gloria Tsai

Steven A. Tuch
Ruth Lopez Turley

Bryan Turner

R. Jay Turner

Stephen Turner

Karolyn D. Tyson

Lynet Uttal

Nicholas Valentino

Steven Vallas

Stephen Valocchi

Debra Van Ausdale

Nella Van Dyke

Jenny Van Hook

Yael Van Hulst

Aimee Van Wagenen

Tom Vander Ven

Diane Vaughan

Suzanne Vaughan

William Velez

Salvador Vidal-Ortiz

Kim Voss

Patricia Voydanoff

Faye Wachs

Tim Wadsworth

Theodore Wagenaar

Stephanie Wahab

John M. Wallace

Steven P. Wallace

Maureen R. Waller

Glenn D. Walters

John Walton

Susan Walzer

Jane Ward

Kee Warner

John "Rob" Warren

Mark Warren

Cynthia A. Warrick

Lisa H. Weasel

Stephen Webster

Jill Weigt

Darin Weinberg

Elliot Weininger

Ronald Weitzer

Sandy Welsh

Harold Wenglinsky

Regina Werum

Candace West

Rachel Bridges Whaley

Amy S. Wharton

Darren Wheelock

Michelle White

Nancy Whittier

Owen Whooley

Martin Whyte

Larry Wieder

Pamela Wilcox

Melissa Wilde

Rima Wilkes 
Marion Willetts Chris Williams Danny Williams Gwyneth Williams Jean Williams Jerry Williams Kristi Williams Lindy B. Williams Richard Williams Colwick M. Wilson John Wilson Thomas C. Wilson Bill Winders Terri Winnick
Janet Wirth-Cauchon Judith Wittner Rachael Woldoff Diane Wolf Mark Wolfson Michelle J. Wolkomir Nancy A. Wonders James R. Wood Richard Wood John Wooldredge Eric R. Wright John Paul Wright Diane Wysocki George Yancey
Xiushi Yang

John Yinger

Jan Yoder

Richard York

Alford A. Young

Michael P. Young

Robert Young

Maurice Zeitlin

Dingxin Zhao

Lisa Anne Zilney

Don H. Zimmerman

Mark Zimny

Franklin Zimring

Barbara Zsembik 